\title{
Higher diversity of ammonia/ammonium-oxidizing prokaryotes in constructed freshwater wetland than natural coastal marine wetland
}

\author{
Yong-Feng Wang $\cdot$ Ji-Dong Gu
}

Received: 22 August 2012 /Revised: 7 September 2012 / Accepted: 9 September 2012 /Published online: 9 October 2012

(C) The Author(s) 2012. This article is published with open access at Springerlink.com

\begin{abstract}
Anaerobic ammonium-oxidizing (anammox) bacteria, aerobic ammonia-oxidizing archaea (AOA), and ammonia-oxidizing bacteria (AOB) are three groups of ammonium/ammonia-oxidizing prokaryotes (AOPs) that are involved in the nitrogen cycle. This research compared the AOP communities in a constructed freshwater wetland with a natural coastal marine wetland in the subtropical Hong Kong. Both vegetated/rhizosphere and nonvegetated sediments were investigated to identify the effects of different macrophytes on the AOP communities. The polymerase chain reaction (PCR)-amplified gene fragments of $16 \mathrm{~S}$ rRNA and archaeal and bacterial amoA (encoding the ammonia monooxygenase alpha subunit) were applied as molecular biomarkers to analyze the AOPs' phylogeny and diversity. Quantitative PCR was used to determine the abundances of AOPs in the sediments. The results showed that the relatively more heterogeneous freshwater wetland contained a broader range of phylotypes, higher diversity, more complex community structures, and more unevenly distributed abundances of AOPs than the coastal wetland. The effects of vegetation on the community structures of AOPs were plant-specific. The exotic Typha angustifolia
\end{abstract}

Electronic supplementary material The online version of this article (doi:10.1007/s00253-012-4430-4) contains supplementary material, which is available to authorized users.

Y.-F. Wang · J.-D. Gu $(\bowtie)$

Laboratory of Environmental Microbiology and Toxicology,

School of Biological Sciences, The University of Hong Kong,

Pokfulam Road,

Hong Kong, SAR, People's Republic of China

e-mail: jdgu@hkucc.hku.hk

J.-D. Gu

The Swire Institute of Marine Science,

The University of Hong Kong,

Shek O, Cape d'Aguilar,

Hong Kong, SAR, People's Republic of China affected the community structures of all AOPs and enhanced their abundances in the rhizosphere region. Both Phragmites australis and Cyperus malaccensis showed some effects on the community structures of $\mathrm{AOB}$, but minimal effects on those of anammox bacteria or AOA. Kandelia obovata had almost no detectable effect on all AOPs due to their smaller size. This study suggested that the freshwater and coastal marine wetlands may have different contributions to the inorganic $\mathrm{N}$ removal due to the variations in AOP communities and plant types.

Keywords Anammox bacteria $\cdot$ Ammonia-oxidizing archaea $\cdot$ Ammonia-oxidizing bacteria $\cdot a m o A \cdot$ Mangrove . Diversity $\cdot$ Wetland $\cdot$ Subtropical

\section{Introduction}

Ammonium/ammonia-oxidizing prokaryotes (AOPs) contribute to ammonia oxidation in the global nitrogen cycle, including anaerobic ammonium oxidation (anammox) and aerobic ammonia oxidization. Anammox, the process in which ammonium is transformed with nitrite to dinitrogen gas $\left(\mathrm{N}_{2}\right)$, was first discovered from a wastewater treatment plant (Mulder et al. 1995). All known anammox bacteria belong to five genera in the phylum Planctomycetales: Candidatus Brocadia (Strous et al. 1999), Ca. Kuenenia (Schmid et al. 2000), Ca. Scalindua (Schmid et al. 2003), $\mathrm{Ca}$. Anammoxoglobus (Kartal et al. 2007), and $\mathrm{Ca}$. Jettenia (Quan et al. 2008). No pure cultures of anammox bacteria have been obtained due to their notoriously slow growth rate (Jetten et al. 1998, 2009). In addition to the application to inorganic $\mathrm{N}$ removal in sewage treatment (Kartal et al. 2010), anammox bacteria have been demonstrated to play a significant role in marine environments, including the anoxic basin of the Black Sea (Kuypers et al. 2003), the 
Benguela and Peru upwelling systems (Kuypers et al. 2005; Lam et al. 2009), the sediments of the South China Sea and Jiaozhou Bay of China (Dang et al. 2010; Hong et al. 2011), coastal and estuary sediments (Dale et al. 2009; Li et al. 2011b), oil fields ( $\mathrm{Li}$ et al. 2010a), and even polar marine sediments and sea ice (Rysgaard and Glud 2004). It was estimated that anammox bacteria might be responsible for more than $50 \%$ of global nitrogen losses from the oceans (Brandes et al. 2007). In addition to marine environments, anammox bacteria were also detected in freshwater and terrestrial environments such as lakes (Hamersley et al. 2009; Schubert et al. 2006), rivers (Zhang et al. 2007), terrestrial soils (Penton et al. 2006), paddy fields (Wang and $\mathrm{Gu}$ 2012), groundwater (Clark et al. 2008), hot springs (Jaeschke et al. 2009), and coastal mangrove wetlands (Cao et al. 2011a; Li et al. 2011a, b). Functional genes encoding hydrazine oxidoreductase (hzo), nitrite reductase (nir), and hydrazine synthase ( $h z s)$ have been used to detect anammox bacteria in natural environments (Harhangi et al. 2012; Li et al. 2010b; Schmid et al. 2008), but the more widely used molecular biomarker is still the $16 \mathrm{~S}$ rRNA gene ( $\mathrm{Li}$ and $\mathrm{Gu}$ 2011).

Aerobic ammonia oxidation is the first and rate-limiting step in nitrification (Purkhold et al. 2000), through which ammonia is oxidized with oxygen to nitrite by two phylogenetically distinct microbial groups: ammonia-oxidizing bacteria (AOB) and ammonia-oxidizing archaea (AOA). $\mathrm{AOB}$ were found capable of catalyzing this process more than one century ago (Winogradsky 1890). To date, all known AOB fall into two phylogenetic lineages within the $\beta$ - and $\gamma$-Proteobacteria (reviewed by Kowalchuk and Stephen 2001). In addition to AOB, the newly discovered AOA are also able to oxidize ammonia to nitrite under aerobic conditions (Könneke et al. 2005). AOA was initially classified into the phylum Crenarchaeota (Könneke et al. 2005) and later into the newly proposed phylum Thaumarchaeota based on genomic level comparison (Brochier-Armanet et al. 2008; Pester et al. 2011). Although AOB and AOA belong to different domains, both of them contain homologous ammonia monooxygenase (Amo), which oxidizes ammonia with oxygen to hydroxylamine. The gene amoA, encoding the alpha subunit of Amo, is widely used as a functional marker to analyze the phylogeny and abundance of AOB and AOA in the environments (Francis et al. 2005; Rotthauwe et al. 1997).

Wetlands are an important ecosystem for their ecological functions by offering habitats (Nagelkerken et al. 2008), supporting abundant life (Nagelkerken et al. 2008), possessing high diversity (Gopal and Ghosh 2008), and purifying water (Michael 2010). Plants are the most important primary producers in wetlands. In addition to being highly productive, plants affect nutrient cycling in the wetland by transferring oxygen to the vicinity of roots and form a special microenvironment around the rhizosphere that is different from the bulk soil and the nonvegetated soil (Zhang et al. 2009). A number of studies have been carried out on AOP communities in wetlands, particularly in the rhizospheres (Cao et al. 2011a, b, 2012; Dale et al. 2009; Herrmann et al. 2008, 2009; Li et al. 2011b). However, the related research reports are still very limited. For example, are AOP communities in the coastal wetland and the freshwater wetland different? Is the effect of the rhizosphere on the AOP community plant-specific? The coastal and the freshwater wetlands are essentially different because they are respectively under the influence of seawater and freshwater of different physiochemical characteristics. Because AOPs have been shown to have separate niches (Schleper 2010), it can be assumed that AOP communities in different types of wetlands are different. In addition, AOP communities in vegetated sediments might be different from the nonvegetated ones. In order to verify our hypothesis, we investigated AOP communities in the rhizosphere and the nonvegetated sediments in a natural coastal wetland and a constructed freshwater wetland in the subtropical Hong Kong using the molecular biomarkers 16S rRNA gene and archaeal and bacterial amoA genes. Through this study, we would like to further our understanding and knowledge about the effects of the wetland type and the rhizospheres of different plants on AOP communities.

\section{Materials and methods}

\section{Description of sites and sampling}

The natural coastal wetland is located at Tai $\mathrm{O}\left(22^{\circ} 14^{\prime} 59^{\prime \prime}\right.$ N, 113 $51^{\prime} 43^{\prime \prime}$ E) in subtropical Hong Kong (Supplement material Fig. S1), restored from deserted salt pans about 40 years ago with mangrove trees Kandelia obovata being the dominant plants. Samples were taken by layers at the depths of $0-2,4-6,9-11,14-16,19-21,24-26,29-31$, and $39-41 \mathrm{~cm}$ at both vegetated and nonvegetated sites on March 13, 2009, the end of dry season and the beginning of wet season in Hong Kong. The nonvegetated sampling site was about $10 \mathrm{~m}$ away from the vegetated one. The overlying water at each site was also collected for physiochemical analyses in laboratory.

The constructed freshwater wetland is located at Yuen Long $\left(22^{\circ} 27^{\prime} 20^{\prime \prime} \mathrm{N}, 114^{\circ} 2^{\prime} 43^{\prime \prime}\right.$ E) in Hong Kong (Supplement material Fig. S1), transformed from three fishponds in 2003 for creating a wetland habitat for wild birds, amphibians, and dragonflies. Aquatic macrophytes Phragmites australis, Typha angustifolia, and Cyperus malaccensis were dominant plants at the upstream, middle stream, and downstream of the wetland, respectively. The input water of the wetland was made 
up of runoff from adjacent hills mixed with a small fraction of wastewater from nearby villages. Sediment samples were respectively taken from the sites grown with $P$. australis, T. angustifolia, and C. malaccensis on March 24, 2009. At each site, the rhizosphere sediments of the plants and the adjacent nonvegetated sediments about $10 \mathrm{~m}$ away were collected. The overlying water at each site was also collected for physiochemical analyses.

All sediment and water samples were immediately put into ice boxes and transported back to the laboratory shortly after collection. In the laboratory, samples for subsequent molecular studies were kept at $-80{ }^{\circ} \mathrm{C}$ and samples for physiochemical analysis were processed immediately.

Physiochemical analyses

The temperature, $\mathrm{pH}$, and redox potentials of the sediments and water were measured in situ with the IQ160 $\mathrm{pH}$ meter (with ORP electrode) (IQ Scientific Instruments, Inc.). The conductivity, turbidity, and salinity of the water were measured in situ with the Water Quality Checker U-10 (HORIBA). Inorganic $\mathrm{N}$ of the sediments was extracted with $2 \mathrm{M} \mathrm{KCl}$ in 1:4 ratio (sediment to solution) for $1 \mathrm{~h}$. Ammonia-N, nitrite- $\mathrm{N}$, and nitrate- $\mathrm{N}$ of the extracts, as well as of the overlying water collected from the two wetlands, were determined with the Lachat QuikChem 8000 Flow Injection Analyzer (Lachat Instruments Inc.). The measuring procedures were in accordance with the manual of the instrument. Sediment dry weights were measured after drying in an oven at $105^{\circ} \mathrm{C}$ for $24 \mathrm{~h}$ till constant weight was achieved.

\section{Sediment DNA extraction and PCR amplification}

Sediment total DNA was extracted using the SoilMaster DNA Extraction Kit (Epicentre Biotechnologies, Madison, WI, USA) according to the manual of the manufacturer within 1 month after sample collection. DNA was finally eluted with $250 \mu \mathrm{l}$ of TE buffer included in the kit. The extracted sediment DNA was then used for subsequent molecular analysis and stored at $-20{ }^{\circ} \mathrm{C}$ after use. Anammox bacterial 16S rRNA gene fragments and archaeal and bacterial amoA genes were amplified using the GoTaq Flexi DNA Polymerase Kit (Promega, Hong Kong) with different protocols described below.

The 16S rRNA gene fragments of anammox bacteria were amplified using Amx368F (5'-TTCGCAATGCCCGAAAGG$\left.3^{\prime}\right)$ and Amx820R (5'-AAAACCCCTCTACTTAGTGCCC$\left.3^{\prime}\right)$. The optimized polymerase chain reaction (PCR) mixture contained, in a final volume of $50 \mu \mathrm{l}$, as follows: $1.5 \mu \mathrm{l}$ of DNA $\left(20 \mathrm{ng} \mu \mathrm{l}^{-1}\right), 10 \mu \mathrm{l}$ of $5 \times$ GoTaq Flexi Buffer (Promega, Hong Kong), $4 \mu$ of $\mathrm{MgCl}_{2}$ ( $25 \mathrm{mM}$; Promega, Hong Kong), $1 \mu \mathrm{l}$ of deoxyribonucleotide triphosphates (dNTPs; $10 \mathrm{mM}$ of each; Promega, Hong Kong), $1 \mu$ l of each forward and reverse primers $(20 \mu \mathrm{M}), 0.25 \mu \mathrm{l}$ of GoTaq Flexi Polymerase

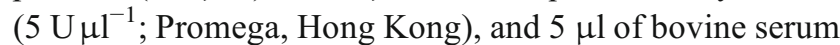
albumin (BSA; $0.1 \%$ ). PCR conditions were set as follows: $94{ }^{\circ} \mathrm{C}$ for $4 \mathrm{~min} ; 30$ cycles of $95^{\circ} \mathrm{C}$ for $45 \mathrm{~s}, 59^{\circ} \mathrm{C}$ for $50 \mathrm{~s}$, followed by $72{ }^{\circ} \mathrm{C}$ for $1 \mathrm{~min}$; and finally, $72{ }^{\circ} \mathrm{C}$ for $15 \mathrm{~min}$.

The archaeal amoA genes were amplified using the primers Arch-amoAF (5'-STAATGGTCTGGCTTAGACG-3') and Arch-amoAR (5'-GCGGCCATCCATCTGTATGT-3'). Based on the standard procedures in the manufacturer's instructions and results of previous studies (Francis et al. 2005), the optimized PCR mixture contained, in a final volume of $50 \mu$, as follows: $1.5 \mu$ l of DNA $\left(20 \mathrm{ng}^{-1} \mathrm{l}^{-1}\right), 10 \mu \mathrm{l}$ of $5 \times$ GoTaq Flexi Buffer (Promega, Hong Kong), $3 \mu$ of $\mathrm{MgCl}_{2}$ ( $25 \mathrm{mM}$; Promega, Hong Kong), $1 \mu \mathrm{l}$ of dNTPs (10 mM of each; Promega, Hong Kong), $1 \mu$ l of each forward and reverse primers $(20 \mu \mathrm{M}), 0.25 \mu \mathrm{l}$ of GoTaq Flexi Polymerase

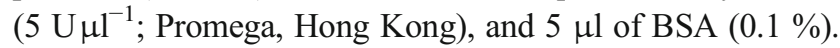
PCR conditions were set as follows: $95^{\circ} \mathrm{C}$ for $5 \mathrm{~min} ; 30$ cycles of $94{ }^{\circ} \mathrm{C}$ for $45 \mathrm{~s}, 53{ }^{\circ} \mathrm{C}$ for $1 \mathrm{~min}$, and $72{ }^{\circ} \mathrm{C}$ for $1 \mathrm{~min}$; and finally, $72^{\circ} \mathrm{C}$ for $15 \mathrm{~min}$.

The bacterial amo $A$ genes were amplified using the primers amo $A$-1F (5'-GGGGGTTTCTACTGGTGGT-3') and amoA-2R (5'-CCCCTCKGSAAAGCCTTCTTC-3'). The optimized PCR mixture contained, in a final volume of $50 \mu \mathrm{l}$, as follows: $1.5 \mu \mathrm{l}$ of DNA $\left(20 \mathrm{ng} \mu \mathrm{l}^{-1}\right), 10 \mu \mathrm{l}$ of $5 \times$ GoTaq Flexi Buffer (Promega, Hong Kong), $2.5 \mu \mathrm{l}$ of $\mathrm{MgCl}_{2}$ (25 mM; Promega, Hong Kong), $1 \mu \mathrm{l}$ of dNTPs (10 mM of each; Promega, Hong Kong), $1 \mu \mathrm{l}$ of each forward and reverse primers $(20 \mu \mathrm{M}), 0.25 \mu \mathrm{l}$ of GoTaq

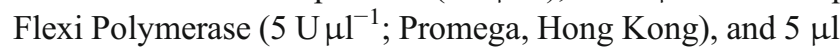
of BSA $(0.1 \%)$. PCR conditions were set as follows: $94{ }^{\circ} \mathrm{C}$ for $3 \mathrm{~min}$; 30 cycles of $94{ }^{\circ} \mathrm{C}$ for $45 \mathrm{~s}, 55^{\circ} \mathrm{C}$ for $45 \mathrm{~s}$, and $72{ }^{\circ} \mathrm{C}$ for $50 \mathrm{~s}$; and finally, $72{ }^{\circ} \mathrm{C}$ for $10 \mathrm{~min}$.

PCR products were checked by electrophoresis on $1 \%$ agarose gel staining with ethidium bromide $\left(0.5 \mu \mathrm{gml}^{-1}\right)$.

\section{Cloning and sequencing}

All the PCR-amplified products were purified through cutting gel bands with a Gel Advanced ${ }^{\mathrm{TM}}$ Gel Extraction System (Viogene-Bio Tek Co., Taiwan, Republic of China) according to the manufacturer's instructions. The purified products were ligated into the pMD18 T-vector (Takara, Japan) and then transformed into the host Escherichia coli DH5 $\alpha$ competent cell (Takara, Japan) in accordance with the manufacturer's instructions. Clones were randomly selected and insertions of an appropriate-sized DNA fragment were determined by PCR amplification with the primer set M13F and M13R. Positive clones were then sequenced with ABI 3730xl DNA Analyzer (Applied Biosystems) at the Genome Research Centre of The University of Hong Kong. 
Analyses of phylogeny, rarefaction, richness, and diversity

Sequences were analyzed against those in the GenBank with BLAST and Ribosomal Database Project II (Altschul et al. 1990; Cole et al. 2005). They were aligned and phylogenetic trees were constructed using MEGA, version 5.1 (Tamura et al. 2011). For anammox bacteria, clones with more than $99 \%$ nucleotide sequence similarity were grouped into the same operational taxonomic unit (OTU), and their representative sequences were used for phylogenetic analysis. For $\mathrm{AOA}$ and $\mathrm{AOB}$, clones with more than $97 \%$ putative amino acid sequence similarity were grouped into the same OTU, and their representative sequences were used for phylogenetic analysis. Phylogenetic trees were constructed with the neighbor-joining method with 1,000 bootstrap repetitions to estimate the confidence of the tree topologies.

To compare anammox bacterial 16S rRNA and archaeal and bacterial amoA gene-based richness and diversity within each clone library, rarefaction, Chao nonparametric richness, and Shannon indices of diversity were calculated using DOTUR (Schloss and Handelsman 2005).

\section{Real-time quantitative PCR analysis}

The abundances of anammox bacterial 16S rRNA genes and archaeal and bacterial amoA genes were determined in triplicate with real-time quantitative PCR amplification using a FastStart Universal SYBR Green Master (Rox) Kit (Roche, Germany). Real-time quantitative PCR was performed in 96well optical plates placed in the ABI PRISM ${ }^{\circledR} 7000$ Sequence Detection System (Applied Biosystems). The primer set composed of Amx368F and Amx820R was used for the amplification of 16S rRNA genes of anammox bacteria. The primer set composed of Arch-amoAF and Arch-amoAR was used for the amplification of the amoA genes of AOA, and the primer set composed of amoA-1F and $a m o A-2 \mathrm{R}$ was used for the amplification of the $a m o A$ genes of AOB. The final reaction volume was $20 \mu \mathrm{l}$ and the reaction composition and cycling conditions were in accordance with the manual.

The specificity of the PCR amplification was determined by the melting curve and gel electrophoresis. Cycle thresholds were determined by comparing with the standard curves constructed using a 10-fold serial dilution $\left(10^{2}-10^{7}\right.$ gene copies $\left.\mu \mathrm{l}^{-1}\right)$ of the newly extracted plasmids containing the corresponding gene fragments. Relative copy numbers among target groups were evaluated, and some replicates of apparent discrepancy were excluded in order to decrease standard error. The correlation coefficient $R^{2}$ values were $>0.97$ for all of the standard curves.

PCoA analysis

Fast UniFrac provides a suite of tools for the comparison of microbial communities using phylogenetic information
(Hamady et al. 2009). To compare microbial communities in different environments, the phylogenetic trees of anammox bacteria, AOA, and AOB were analyzed online using Jackknife environment clusters analysis (UPGMA algorithm with 100 replicates Jackknife supporting test) and principal coordinates analysis $(\mathrm{PCoA})$ on the website of Fast UniFrac (http://bmf2.colorado.edu/fastunifrac/).

Nucleotide sequence accession numbers

The anammox bacterial 16S rRNA gene sequences determined in this study are available in GenBank under accession numbers JQ886186 to JQ886236, AOA amoA gene sequences under accession numbers JQ886237 to JQ886313, and AOB amoA gene sequences under accession numbers JQ886314 to JQ886397.

\section{Results}

Physiochemical characteristics of sediment samples

When considering wetland type, the coastal marine wetland and the freshwater wetland had very different physiochemical characteristics (Table 1). Firstly, the average salinity, conductivity, and turbidity of the overlying water from the coastal wetland were $2.97 \%, 45.40 \mathrm{mS} \mathrm{cm}^{-1}$, and $5.9 \mathrm{NTU}$, respectively, much higher than those from the freshwater wetland $\left(0.05 \%, 1.23 \mathrm{mS} \mathrm{cm}^{-1}\right.$, and $1.7 \mathrm{NTU}$, respectively). Secondly, the average $\mathrm{NH}_{4}{ }^{+}$concentration of the sediments from the coastal wetland was $1.68 \mu \mathrm{g} \mathrm{Ng}^{-1} \mathrm{DW}$, higher than $0.36 \mu \mathrm{g} \mathrm{Ng}^{-1} \mathrm{DW}$ of those from the freshwater wetland. However, the average $\mathrm{NO}_{2}{ }^{-}$and $\mathrm{NO}_{3}{ }^{-}$concentrations of the sediments from the coastal wetland were 0.02 and $0.12 \mu \mathrm{g} \mathrm{Ng}^{-1} \mathrm{DW}$, respectively, lower than those from the freshwater wetland $\left(0.15\right.$ and $0.18 \mu \mathrm{g} \mathrm{Ng}^{-1} \mathrm{DW}$, respectively). Thirdly, the average $\mathrm{pH}$ of the sediments from the coastal wetland was 7.1, much higher than 5.4 of those from the freshwater wetland.

When taking into account vegetation, vegetated sediments (including the rhizosphere in this study) had apparently different physiochemical properties from those of nonvegetated ones (Table 1). Firstly, the average $\mathrm{NH}_{4}^{+}$ concentration of the vegetated sediments was $0.56 \mu \mathrm{g} \mathrm{Ng}^{-1}$ DW, which was lower than $2.08 \mu \mathrm{g} \mathrm{Ng}^{-1} \mathrm{DW}$ of nonvegetated ones. Secondly, the average $\mathrm{pH}$ of the vegetated sediments was 6.3 , which was lower than 7.0 of the nonvegetated ones. Thirdly, in the freshwater wetland, redox potentials of the vegetated sediments were much higher than those of the corresponding nonvegetated ones (Table 1). In the coastal wetland, however, redox potentials did not show obvious differences between the vegetated and nonvegetated sediments (Table 1). 


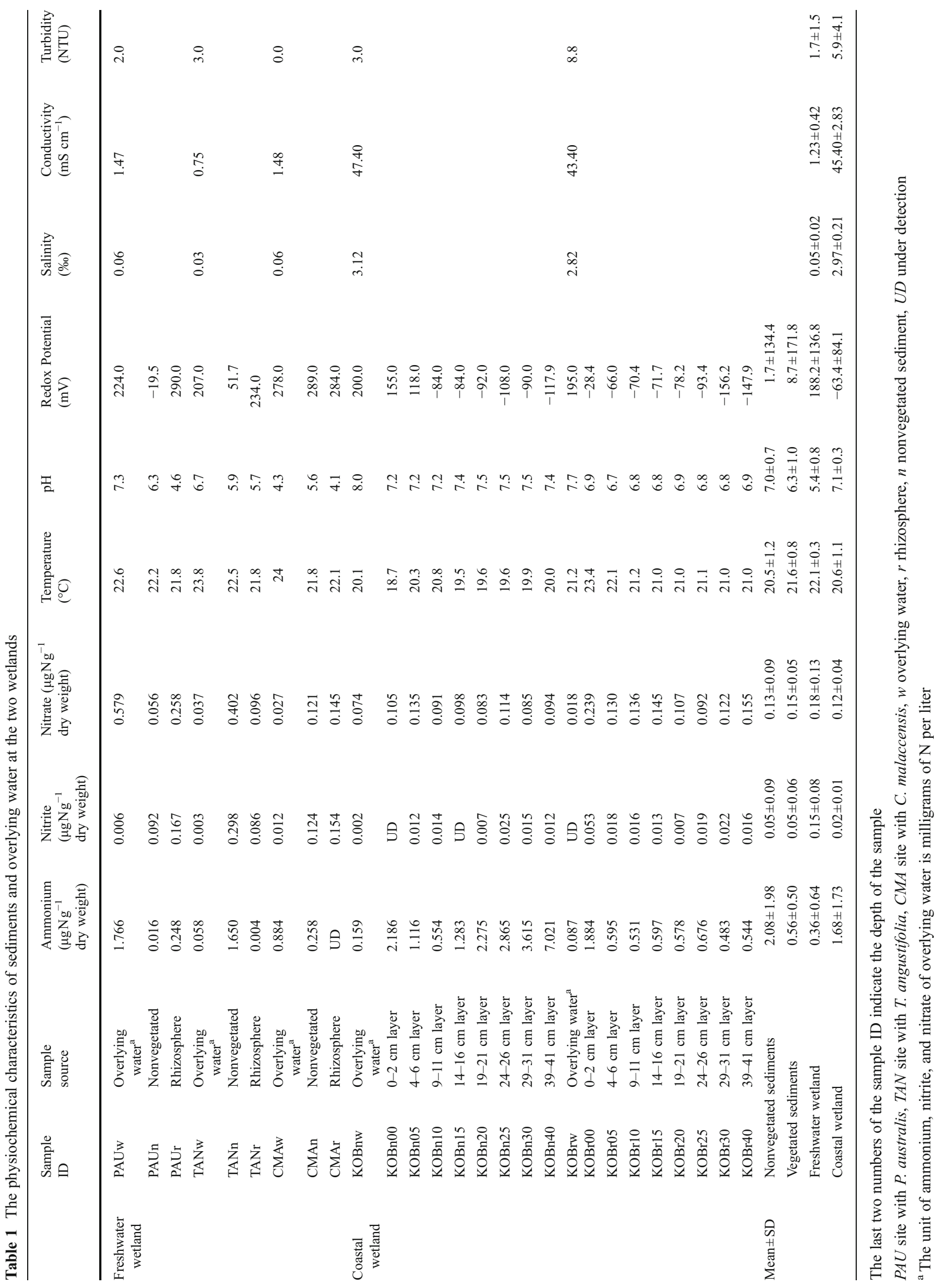


Phylogeny of anammox bacteria, AOA, and AOB

The phylogenetic tree of anammox bacteria in the two wetlands amplified by using $16 \mathrm{~S}$ rRNA genes is shown in Fig. 1a. A total of 248 clones were acquired from all the sediment samples of the two wetlands. Clones with more than $99 \%$ nucleotide sequence similarity were grouped into the same OTU, and their representative sequences were used for phylogenetic analysis. The phylogenetic tree shows that both wetlands, especially
Fig. 1 Phylogenetic trees based on nucleotide sequences of 16S rRNA gene-amplified fragments of anammox bacteria (a) and the $a m o A$ gene sequences of AOA (b) and AOB (c). The tree for anammox bacteria was reconstructed based on partial 16S rRNA sequences (477 nucleotides). The trees for $\mathrm{AOA}$ and $\mathrm{AOB}$ were reconstructed based on partial AmoA sequences (198 and 150 amino acids for AOA and AOB, respectively). For anammox bacteria, clones with more than $99 \%$ nucleotide sequence similarity were grouped into the same OTU; for AOA and AOB, clones with more than $97 \%$ putative amino acid sequence similarity were grouped into the same OTU, and their representative sequences were used for phylogenetic analysis. The numbers of OTUs and total sequences in the libraries are shown in parentheses. Phylogenetic trees were constructed with the neighbor-joining method with 1,000 bootstrap repetitions to estimate the confidence of the tree topologies. Bootstrap values ( $>50 \%)$ are indicated at the branch points. The solid and hollow circles with blue color represent the vegetated and nonvegetated sediments of $K$. obovata, respectively. The solid and hollow triangles with red color represent the rhizospheres and nonvegetated sediments of $P$. australis, respectively. The solid and hollow squares with red color represent the rhizospheres and nonvegetated sediments of T. angustifolia, respectively.

The solid and hollow inverted triangles with red color represent the rhizospheres and nonvegetated sediments of $C$. malaccensis, respectively a

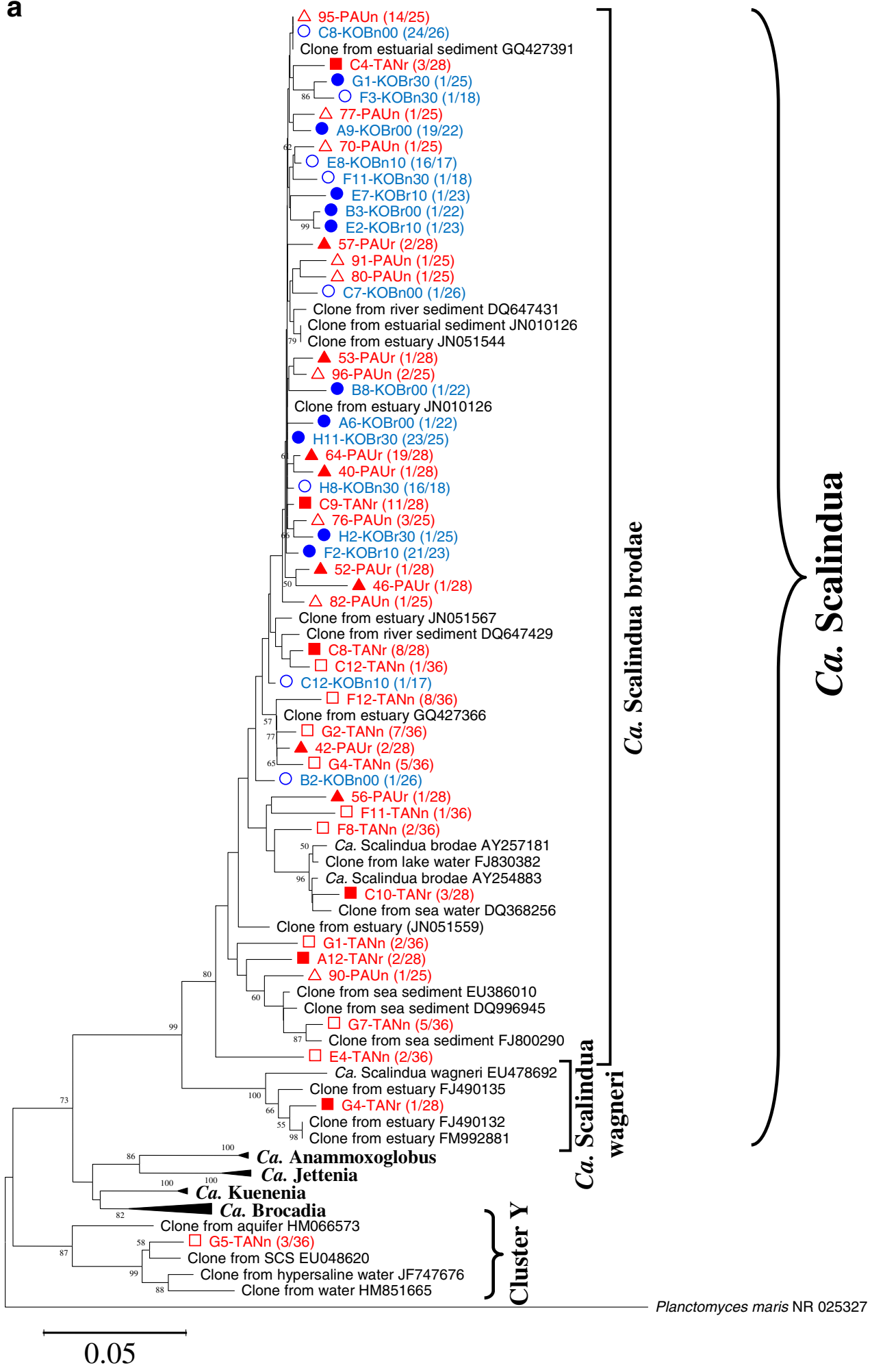


Fig. 1 (continued)

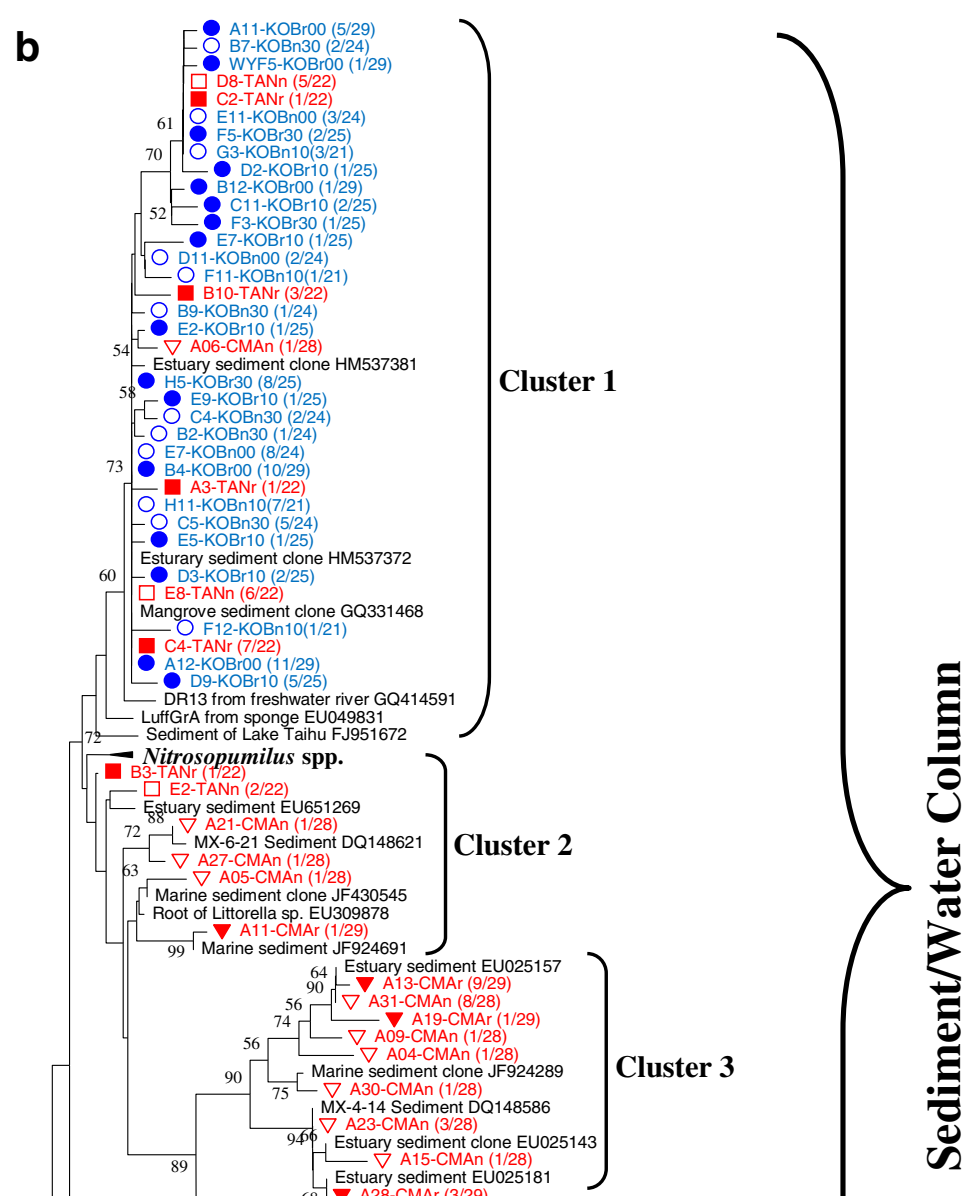

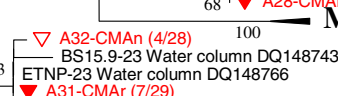

ETNP-16 Water column DQ148759

$\nabla$ A18-CMAr (3/29)

(1) A26-CMAn (1/22)

92

MB-C130m-22 Water column DQ1488

$\sqrt{ }$ SF-NB1-NB1-1 Sediment DQ148633

51 ES-HL-17 Sediment DQ1488

$-\nabla$ A12-CMAn (1/28)

L A03-CMAr (1/29)

E1-KOBr10 (1/25)

Deep sea sediment EU885549

Marine sediment JF24009

H11-KOBr30 (12/25)

C8-KOBn30 (13/24)

B4-TANr (3/22)

G10-KOBr30 (1/25)

H9-KOBOB $30(1 / 25)$

Marine sediment AM988854

Г $\boldsymbol{~ A 1 0 - C M A r ~ ( 1 / 2 9 ) ~}$

Cluster 5

Cluster 4

79 Tributary sediment JN179680

79 B11-TANr (1/22)
B8-TANr (3/22)

B8-TANr (3/22)

D A22-CMAr (1/29)

Cluster 6

Marine water cluster $\mathrm{A}$

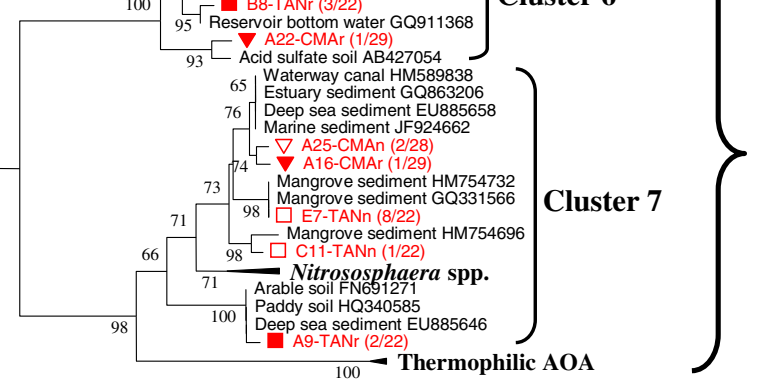

节

0.05 
Fig. 1 (continued)

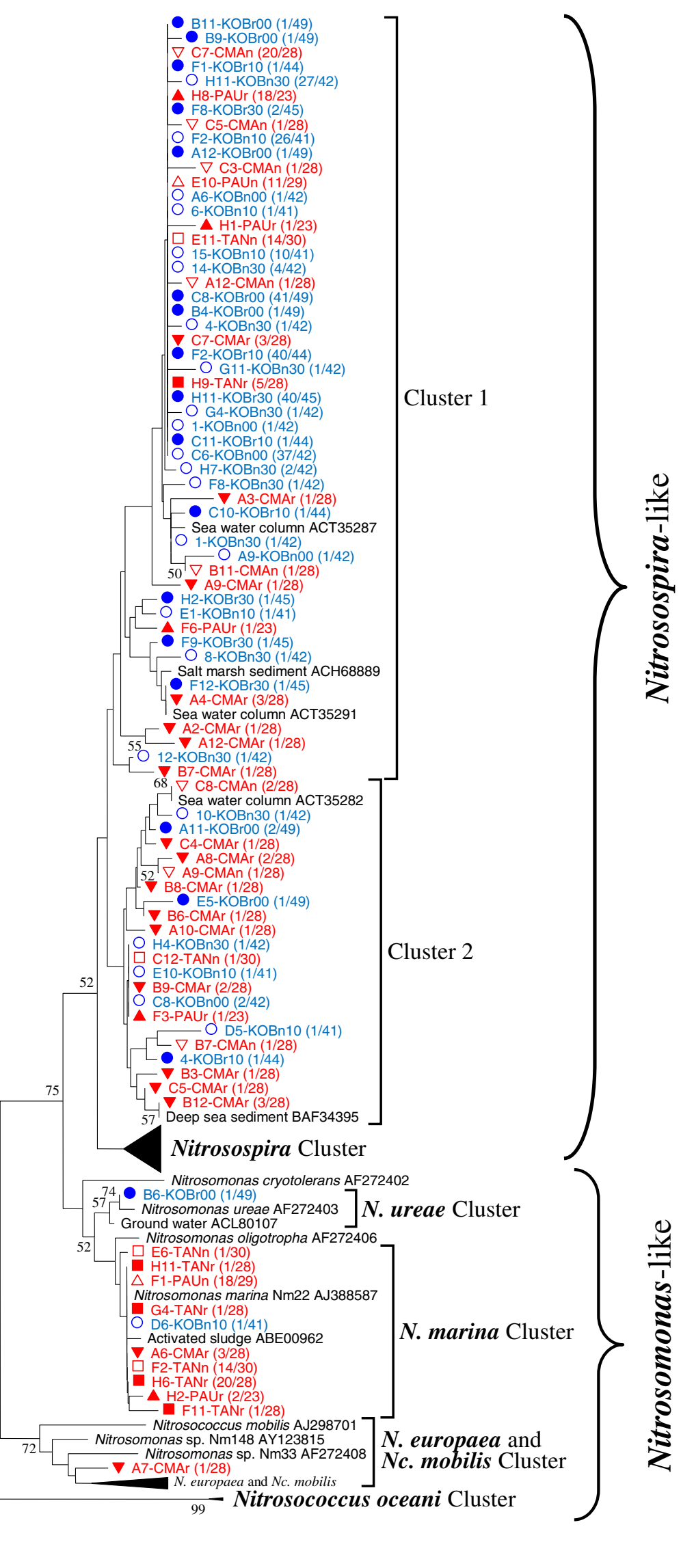


the coastal one, had a narrow range of anammox bacteria phylotypes. All the clones of the coastal wetland (131) were affiliated with $\mathrm{Ca}$. Scalindua brodae. Although the freshwater wetland showed a relatively broader range of phylotypes, the majority of the clones (113 out of 117) fell into $\mathrm{Ca}$. Scalindua brodae, only one clone affiliated with $\mathrm{Ca}$. Scalindua wagneri, and three clones with a unique new cluster Y.

The phylogenetic tree of AOA in the two wetlands analyzed using putative amino acid sequences from the amplified amoA genes is shown in Fig. 1b. A total of 249 archaeal amo $A$ clones were acquired from all the sediment samples of the two wetlands. Clones with more than $97 \%$ putative amino acid sequence similarity were grouped into the same OTU, and their representative sequences were used for phylogenetic analysis. This study adopted the classifying method of Francis et al. (2005), in which AOA sequences were classified by habitats and three clades were defined: sediments, water column, and soil/sediment. The coastal wetland had a narrower range of phylotypes than the freshwater wetland. All clones (148) recovered from the coastal wetland fell into clusters 1 and 4 within the sediments clade. The freshwater wetland showed much broader AOA phylotypes. The sequences retrieved from the freshwater wetland fell into sediment clade (70 out of 101), soil/sediment clade (19 out of 101), and water column clade (12 out of 101). In more detail, they respectively belonged to clusters 1 to 7 , and the water column belonged to cluster A (Fig. 1b).

The phylogenetic tree of AOB in the two wetlands analyzed using putative amino acid sequences of the amplified amoA genes is shown in Fig. 1c. A total of 429 bacterial amoA gene clone sequences were acquired from all the samples of the two wetlands. Clones with more than $97 \%$ putative amino acid sequence similarity were grouped into the same OTU, and their representative sequences were used for phylogenetic analysis. The majority of the clones (365 out of 429) fell into the Nitrosospira-like genus, and the rest (64 out of 429) fell into the Nitrosomonas-like genus. In the Nitrosomonas-like genus, all clones fell into known clusters in which pure cultures have been obtained. In the Nitrosospira-like genus, all the retrieved sequences were affiliated with two unknown clusters, provisionally named cluster 1 (336 clones) and cluster 2 (29 clones). As shown in the AOB phylogenetic tree, the freshwater wetland had a broader range of phylotypes than the coastal marine wetland. For the coastal marine wetland, almost all sequences (261 out of 263) concentrated within the Nitrosospira-like genus, and only two sequences belonged to the Nitrosomonas-like genus. However, for the freshwater wetland, although the majority of them (104 out of 166) were affiliated with the Nitrosospiralike genus, more than one third of the sequences ( 62 out of 166) fell into the Nitrosomonas-like genus.

\section{Diversity of anammox bacteria, $\mathrm{AOA}$, and $\mathrm{AOB}$}

The Shannon index of anammox bacteria in the freshwater wetland was $1.60 \pm 0.36$, much higher than $0.37 \pm 0.11$ in the coastal wetland (Table 2). This result is in agreement with the anammox bacterial phylogenetic tree (Fig. 1a), showing that the freshwater wetland contained a broader range of phylotypes. The rarefaction curve also shows that the freshwater wetland had more OTUs than the coastal wetland (Supplement material Fig. S2).

The Shannon index of AOA in the freshwater wetland was $1.93 \pm 0.39$, higher than $1.40 \pm 0.24$ in the coastal wetland (Table 2). This result is in agreement with the AOA phylogenetic tree that the freshwater wetland had a broader range of AOA phylotypes (Fig. 1b). The rarefaction curve also shows that the freshwater wetland had more OTUs than the coastal wetland (Supplement material Fig. S2).

The Shannon index of AOB in the freshwater wetland was $1.20 \pm 0.78$, higher than $0.79 \pm 0.40$ in the coastal wetland (Table 2). This result is in agreement with the AOB phylogenetic tree in which the freshwater wetland had broader phylotypes than the coastal wetland (Fig. 1c). The rarefaction curve also shows that the freshwater wetland had more AOB OTUs than the coastal wetland (Supplement material Fig. S2).

Community structure comparisons of anammox bacteria, $\mathrm{AOA}$, and $\mathrm{AOB}$

AOP community structure comparisons between the coastal and freshwater wetlands were also analyzed with Jackknife environment clusters analysis and PCoA (Fig. 2). For all AOPs, samples from the coastal wetlands were clustered together, while samples from the freshwater wetland scattered and were not clustered with the samples from the coastal wetland, suggesting that AOP community structures in the two wetlands were different, i.e., the wetland type had an obvious effect on the community structures of AOPs.

In the coastal wetland, the vegetated and nonvegetated samples were clustered together, indicating that community structures of AOPs in the vegetated sediments of $K$. obovata and nonvegetated ones were similar. In the freshwater wetland, the situations were much more complex. For anammox bacteria (Fig. 2a, b), the rhizosphere and nonvegetated samples of $P$. australis site were clustered together, suggesting that the community structures of anammox bacteria in the two samples were similar. However, the rhizosphere and nonvegetated samples of $T$. angustifolia site were not clustered closely, indicating that the community structures of anammox bacteria in the two samples were different. For AOA (Fig. 2c, d), the rhizosphere and nonvegetated sediment samples of the $C$. malaccensis site were not clustered closely, indicating that the community structures of the vegetated and nonvegetated sediments were somewhat 


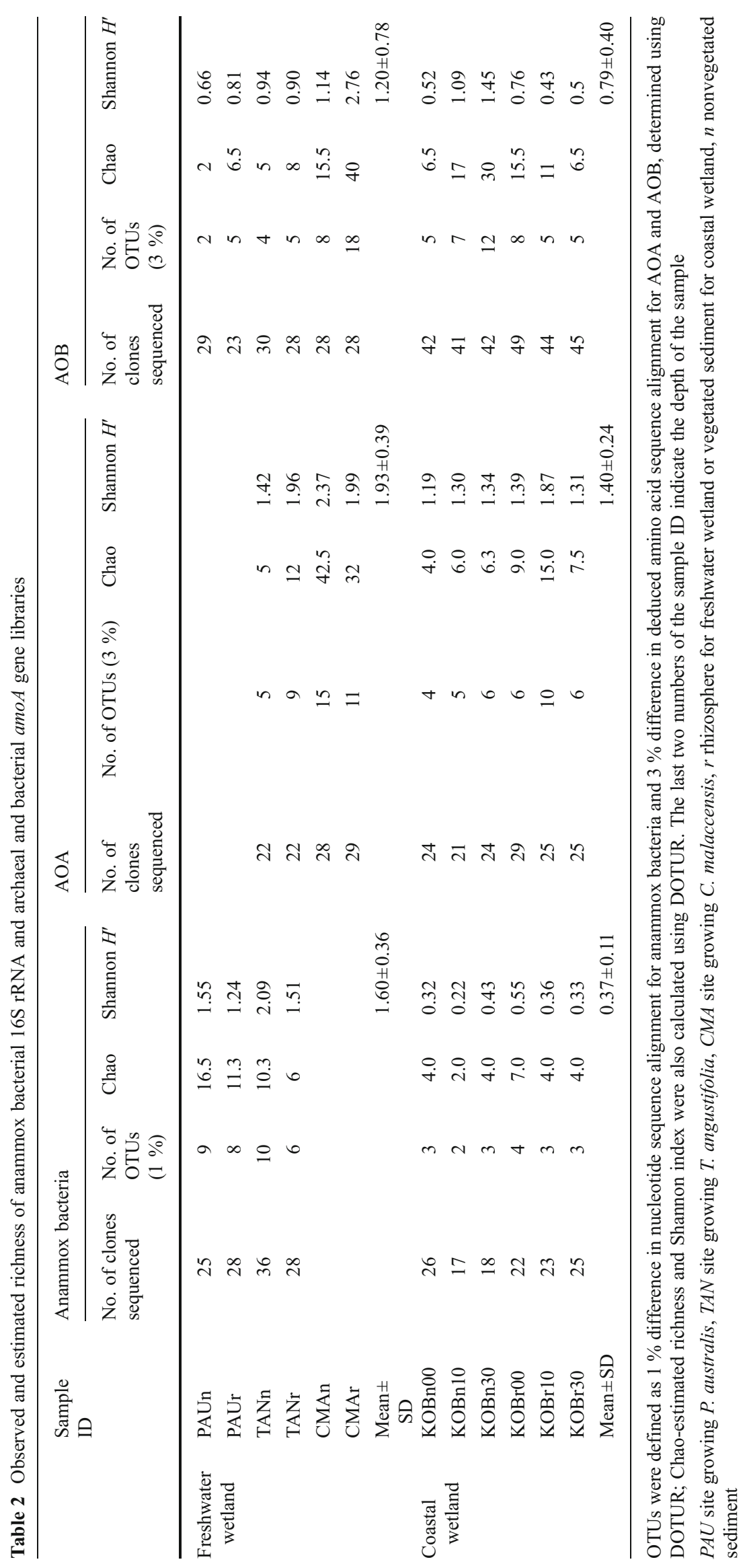


Fig. 2 Jackknife environment clusters analysis (UPGMA algorithm with 100 replicates Jackknife supporting test) and PCoA using the online software Fast UniFrac based on the distance metric of $16 \mathrm{~S}$ rRNA genes of anammox bacteria (a, b), deduced archaeal AmoA amino acid sequences $(\mathbf{c}, \mathbf{d})$, and deduced bacterial AmoA amino acid sequences (e, f), based on the sequence abundance data. For the sample ID, $P A U$ indicates the site with $P$. australis, TAN indicates the site with T. angustifolia, CMA indicates the site with $C$.

malaccensis, $K O B$ indicates the site with $K$. obovata, $r$ indicates rhizosphere or vegetated sediment, $n$ indicates nonvegetated sediment, and the last two numbers indicate the depth of the sample a

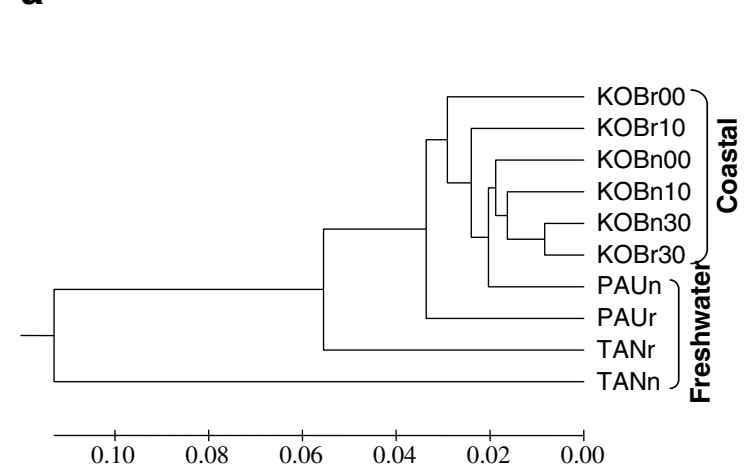

b

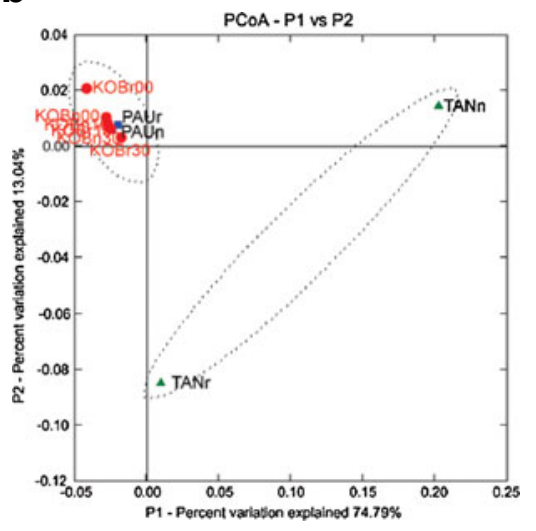

C

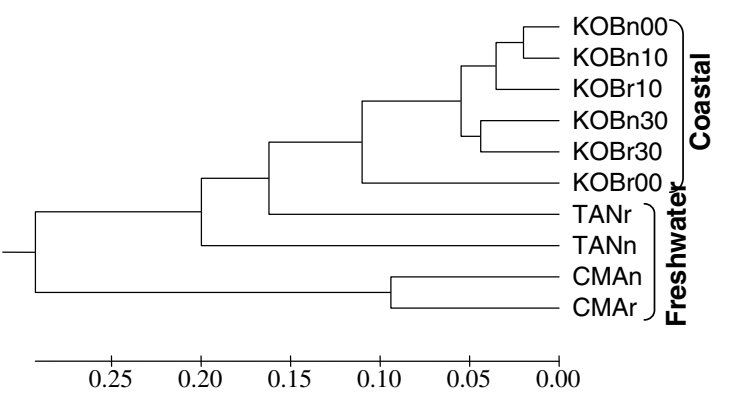

d

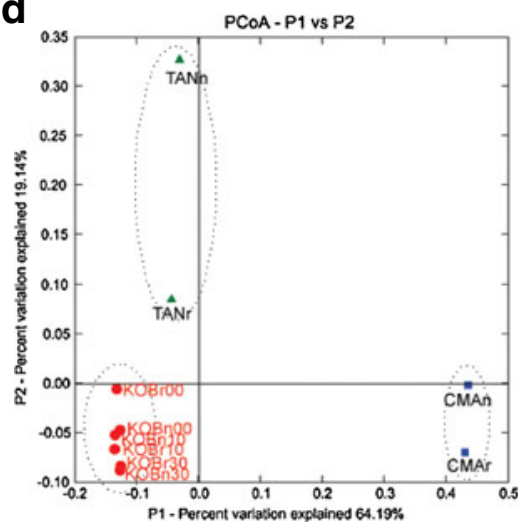

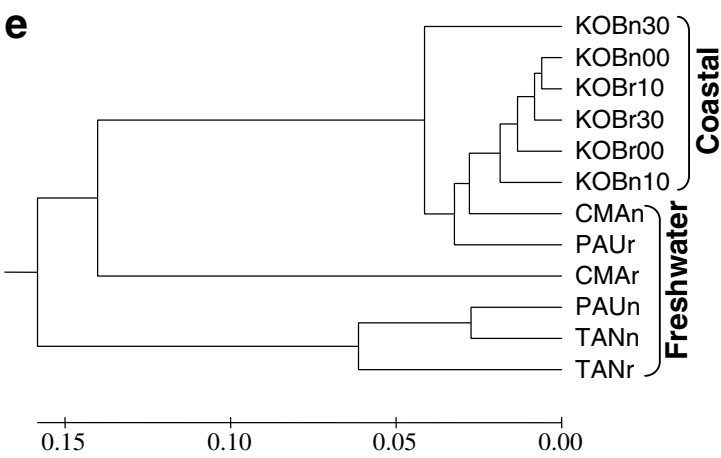

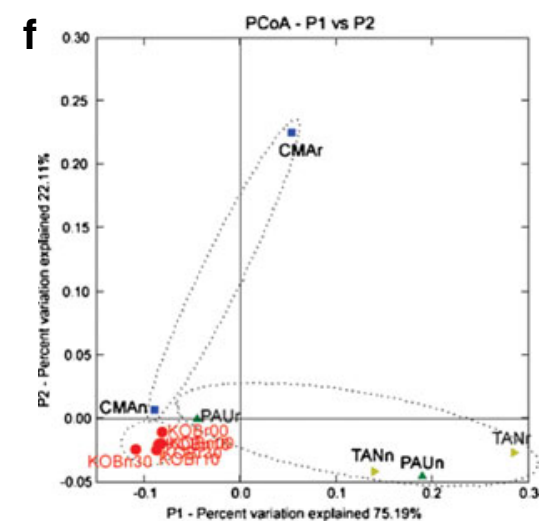

different. The rhizosphere and nonvegetated sediments of the $T$. angustifolia site were not clustered together at all, suggesting that the AOA community structures of the sediments were quite different. For AOB (Fig. 2e, f), the rhizosphere sediments of $P$. australis, $T$. angustifolia, and $C$. malaccensis were not clustered with their adjacent nonvegetated sediments, indicating that the community structures of AOB in the rhizosphere and nonvegetated sediments of $P$. australis, T. angustifolia, and C. malaccensis were different. In summary, $K$. obovata showed almost no effect on the community structures of all AOPs. T. angustifolia had a strong effect on the community structures of all AOPs. $P$. australis and $C$. malaccensis had a certain effect on the community structure of AOB but little effect on the community structures of anammox bacteria and AOA.

Abundance of anammox bacterial 16S rRNA genes and archaeal and bacterial amo $A$ genes

Generally, anammox bacterial 16S rRNA gene abundances in the coastal wetland were higher than those in the freshwater wetland (Fig. 3a). Furthermore, the genes were distributed relatively evenly among different samples in the coastal marine wetland than in the freshwater wetland. In the 
Fig. 3 Abundances of 16S rRNA genes and archaeal and bacterial amo $A$ genes in the vegetated and nonvegetated sediments of the freshwater and coastal wetlands. For the sample ID, $P A U$ indicates the site with $P$. australis, TAN indicates the site with $T$. angustifolia, $C M A$ indicates the site with $C$. malaccensis, $K O B$ indicates the site with $K$. obovata, $r$ indicates rhizosphere or vegetated sediment, $n$ indicates nonvegetated sediment, and the last two numbers indicate the depth of the sample a

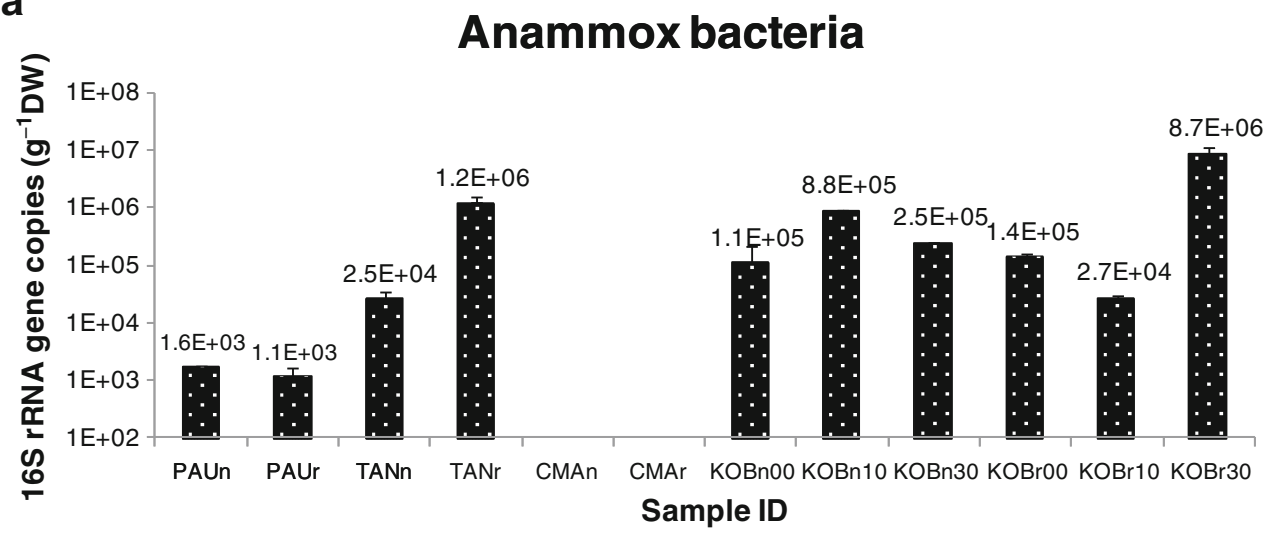

b

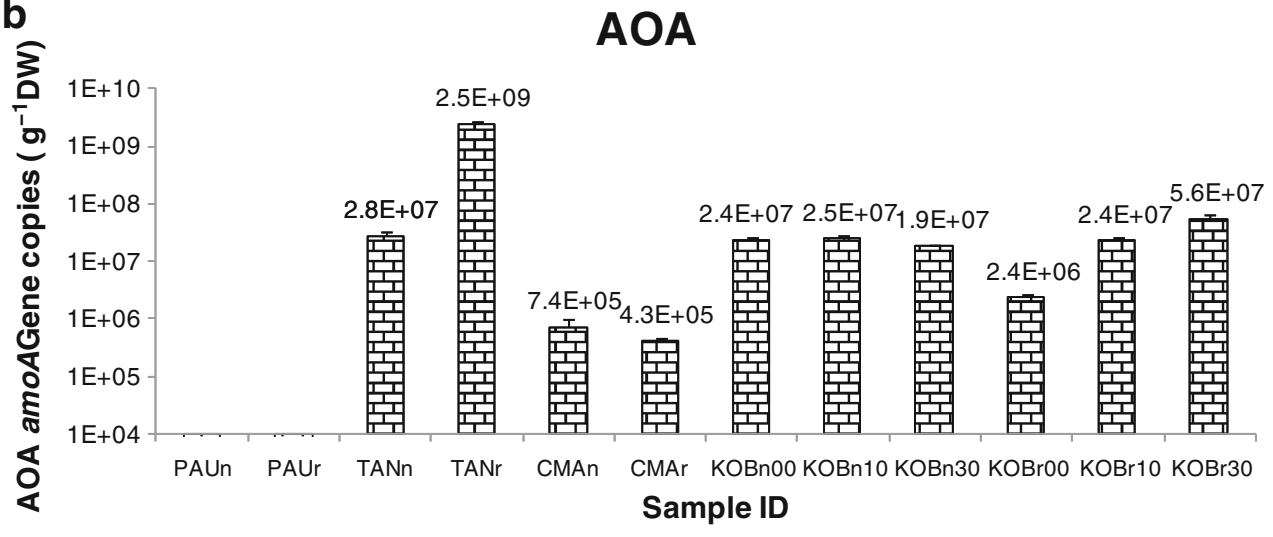

C

高

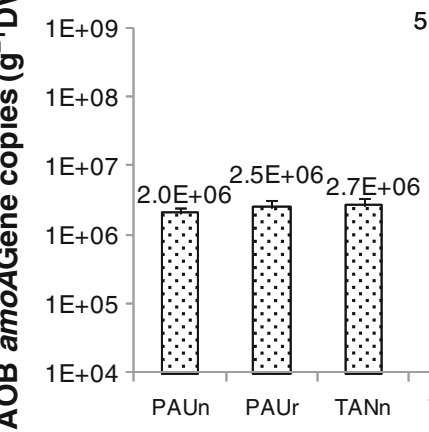

AOB

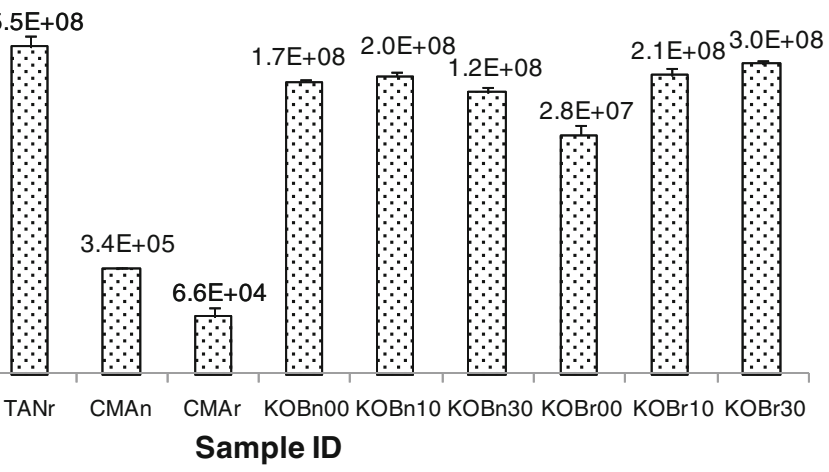

回 $\mathrm{AOA}$ AOB

过

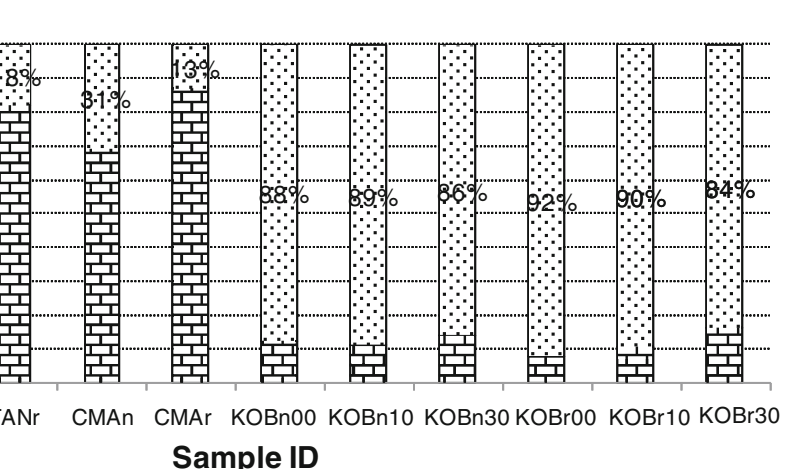


coastal marine wetland, anammox bacterial $16 \mathrm{~S}$ rRNA gene abundances were between $2.7 \times 10^{4}$ and $8.7 \times 10^{6}$ gene copies $\mathrm{g}^{-1}$ DW. In the freshwater wetland, the gene abundances differed significantly at the three sites. No anammox bacteria were detected at the $C$. malaccensis site, but there were up to $1.2 \times$ $10^{6}$ gene copies $\mathrm{g}^{-1} \mathrm{DW}$ in the rhizosphere of T. angustifolia.

AOA amo $A$ genes were distributed relatively evenly between the different samples in the coastal wetland compared to the freshwater wetland (Fig. 3b). The abundances of AOA $a m o A$ genes in the coastal wetland were between $2.4 \times 10^{6}$ and $5.6 \times 10^{7}$ gene copies $g^{-1}$ DW. AOA amo $A$ gene abundances varied significantly between different sites in the freshwater wetland. AOA amoA genes were undetectable at the $P$. australis site; however, they reached $2.5 \times 10^{9}$ gene copies $\mathrm{g}^{-1}$ DW in the rhizosphere of $T$. angustifolia, almost two orders as high as those of the coastal wetland samples.

The abundances of AOB amo $A$ genes were distributed relatively evenly in the coastal marine wetland, between $2.8 \times 10^{7}$ and $3.0 \times 10^{8}$ gene copies $\mathrm{g}^{-1} \mathrm{DW}$ (Fig. $3 \mathrm{c}$ ). AOB amo $A$ gene abundances varied greatly between the different sites in the freshwater wetland, between $3.4 \times 10^{5}$ and $5.5 \times 10^{8}$ gene copies $\mathrm{g}^{-1} \mathrm{DW}$. With the exception of the rhizosphere of T. angustifolia, samples of freshwater wetland generally had lower abundances than samples of the coastal wetland.

The relative abundances of $\mathrm{AOA}$ and $\mathrm{AOB}$ amoA genes in each sediment sample in the two wetlands are shown in Fig. $3 \mathrm{~d}$. The relative abundances of $\mathrm{AOA}$ and $\mathrm{AOB}$ amoA genes were different between the two wetlands. In the freshwater wetland, with the exception of the $P$. australis site where AOA amo $A$ genes were undetectable, the proportion of AOA amo $A$ genes was between 69 and $91 \%$, dominating over AOB amoA genes in all the samples of the other two sites. In the coastal marine wetland, however, the proportion of AOB amo $A$ genes was between 84 and $92 \%$, dominating over AOA amoA genes in all samples.

Taken together, the abundances of anammox bacterial $16 \mathrm{~S}$ rRNA genes and AOA and AOB amo $A$ genes varied significantly between different sites in the freshwater wetland, but they were relatively evenly distributed in different sediment samples of the coastal wetland. The abundances of the AOPs gene copies in the freshwater wetland, except for the site of $T$. angustifolia, were lower than those of the coastal wetland. AOA amoA genes dominated over AOB amo $A$ genes in two out of the three sites in the freshwater wetland. While in the coastal wetland, $\mathrm{AOB}$ amo $A$ genes dominated over AOA amoA genes in all sediment samples.

\section{Discussion}

Physiochemical characteristics of the sediments

The characteristics of sediments in the coastal wetland and the freshwater wetland were quite different (Table 1), indicating that wetland type had an important effect on the characteristics of the sediments. The main reason for the differences is that the two wetlands were respectively under the different effects of seawater and freshwater. Seawater has higher salinity, conductivity, and turbidity than freshwater; therefore, the overlying water of the coastal wetland has higher salinity, conductivity, and turbidity than the freshwater wetland. Seawater is usually slightly alkaline, whereas the freshwater mainly from the runoff of adjacent hills is usually acidic. As a result, sediments in the coastal wetland have higher $\mathrm{pH}$ values than the freshwater wetland. The different sampling strategies may also contribute to the differences of sediment characteristics. In the freshwater wetland, the samples were taken from the rhizosphere and nonvegetated sediments at the depth of approximately $10 \mathrm{~cm}$. In the coastal wetland, however, the samples were taken from layers of different depths (0-40 cm in depth) due to homogeneity. In the deeper layers of the nonvegetated sediments in the coastal wetland, $\mathrm{NH}_{4}{ }^{+}$ concentration was relatively high because no plant roots reached there to absorb them. As a result, the average $\mathrm{NH}_{4}{ }^{+}$ concentration of all samples in the coastal wetland was apparently higher. Deeper layers usually were more anoxic, so redox potentials of the sediments in the coastal wetland were lower compared to the freshwater wetland. Taken together, the physiochemical characteristics of the sediments in the two wetlands were quite different because of a number of reasons. The differences in sediment characteristics will subsequently affect the community of the AOPs in the sediments and form different AOP community structures in these two wetlands.

The vegetated sediments (including the rhizospheres) and nonvegetated sediments had different physiochemical characteristics (Table 1), indicating that vegetation had an effect on the sediment characteristics. In this study, vegetated sediments generally showed lower $\mathrm{NH}_{4}{ }^{+}$concentrations and lower $\mathrm{pH}$, but higher redox potentials. The differences may have resulted from the activity of plants and microorganisms associated with the rhizospheres. Plants in the vegetated sediments absorb $\mathrm{NH}_{4}{ }^{+}$, which will result in relatively lower $\mathrm{NH}_{4}{ }^{+}$concentrations in the vegetated sediments (Ladygina and Hedlund 2010). Enhanced activity of nitrifying microbes might also be a factor for lowering the $\mathrm{NH}_{4}{ }^{+}$concentration observed in the vegetated sediments (Glaser et al. 2010). Plants could change the rhizosphere $\mathrm{pH}$ by 1-2 units (Nye 1981). For example, plants release protons when they absorb $\mathrm{NH}_{4}{ }^{+}$, which could result in the reduction of pH (Ding et al. 2011). Lu et al. (2007) found that mangrove roots could release low-molecular-weight organic acids that resulted in the reduction of $\mathrm{pH}$ by $0.2-0.5$ units in the rhizosphere. In this study, the lower $\mathrm{pH}$ observed in the nonvegetated sediments than the corresponding nonvegetated ones might be due to the activity of plant roots and respiration. Plants could also release the excessive oxygen into the rhizosphere (Nikolausz et al. 2008; Soda et al. 2007), which 
resulted in the higher redox potentials of the vegetated sediments than the corresponding nonvegetated ones in the freshwater wetland. Interestingly, redox potentials in the coastal wetland did not show obvious differences between the vegetated and nonvegetated sediments. Unlike the freshwater wetland, samples taken from the vegetated sites in the coastal wetland were not directly from the rhizospheres but from different layers due to the small mangrove trees. The different layers in the vegetated site were not strongly affected by the direct influence of roots because $K$. obovata in the coastal wetland were still too small (approximately $1.0 \mathrm{~m}$ in height) and the plant roots were not dense enough in the sediments. Because of the activity of roots and rhizosphere microorganisms associated, vegetated sediments had a different physiochemical environment from nonvegetated ones, which will in turn affect the community of the AOPs.

Phylogeny of AOPs in the coastal and freshwater wetlands

In the present study, almost all the clones of anammox bacteria retrieved from the two wetlands were affiliated with the species $C a$. Scalindua brodae. The results agree with previous observations that two different genera of anammox bacteria were seldom found in the same habitat, suggesting that different anammox bacterial genera had different niche specificity (Humbert et al. 2009). The genus $\mathrm{Ca}$. Scalindua was first found in wastewater treatment plant and subsequently detected widely in marine environments (Penton et al. 2006; Schmid et al. 2007). The predominant $C a$. Scalindua brodae found in the present study was also the major component in Lake Tanganyika (Schubert et al. 2006), indicating that $\mathrm{Ca}$. Scalindua could adapt to different environments. In addition to $\mathrm{Ca}$. Scalindua, freshwater species $\mathrm{Ca}$. Kuenenia stuttgartiensis was also reported to be able to gradually adapt to salty water (Kartal et al. 2006). Besides $\mathrm{Ca}$. Scalindua, three clones belonging to the cluster $\mathrm{Y}$ were also retrieved in this study. Cluster $\mathrm{Y}$ have been reported before, and many uncultured clones affiliated with this cluster have been retrieved from different habitats, including the South China Sea (Hong et al. 2011), aquifer water, hypersaline water, and others (Hirsch et al. 2011). However, no pure culture or enrichment has been acquired in the laboratory and their physiology remains unknown. Some studies suggested that clones in cluster $\mathrm{Y}$ are not anammox bacteria and their amplification was due to the primers' nonspecificity (reviewed by Jetten et al. 2009).

Wetland types showed a pronounced effect on the AOA phylotype composition. All clones of AOA in the coastal wetland fell into clusters 1 and 4 within the sediment clade. This is in agreement with early classification because of the marine nature of the coastal wetland. However, the clones of AOA from the freshwater wetland fell into different clades. As shown in previous studies, AOA in the terrestrial ecosystem usually belong to soil/sediment clade (Zhang et al. 2008). The freshwater wetland in this study, however, in addition to the soil/sediment clade, also contained species of sediment clade, and even species of water column clade. This finding challenges previous knowledge and suggests that species in the marine system could also survive in the freshwater wetland. From this point of view, AOA might adapt to a much wider range of habitats. With further studies on AOA from different habitats, more and more species previously believed to only exist in one type of habitat might also occur in other types of habitats (Pester et al. 2012). Although the established scheme by Francis et al. (2005) could correlate AOA species with their ecophysiological characteristics, this method might not be suitable for new findings in the future. A new classification method for AOA has been proposed recently, in which AOA were classified into five phylogenetic clusters named after the first genus found in that cluster (Pester et al. 2012).

The dominant AOB phylotypes in the two wetlands were affiliated with the Nitrosospira-like genus. In the Nitrosospira-like genus, all the retrieved sequences were affiliated with two unknown clusters: clusters 1 and 2 . Although uncultured clones have been reported before in clusters 1 and 2, no pure cultures of them have been acquired to date. The two clusters might be two new uncultured species, which are widely distributed in natural environments. Previous studies have shown that Nitrosospira and Nitrosomonas favor different habitats. Nitrosospira favor clean water of low ammonia, while Nitrosomonas favor polluted environments of high ammonia and frequently in wastewater treatment plants (Okabe et al. 1999). In the present study, the two wetlands were dominated by Nitrosospira-like, suggesting that the two wetlands were not strongly affected by wastewater. Although most Nitrosomonas favor environments of high $\mathrm{NH}_{3}$, Nitrosomonas marina usually exist in marine environments of low $\mathrm{NH}_{3}$ (Pommerening-Röser et al. 1996). In this study, most of the Nitrosomonas-like sequences retrieved from the two wetlands were close to $N$. marina, which further suggests that the two wetlands were not affected by intense anthropogenic pollution. Although Nitrosospira-like dominated both wetlands, the community compositions of AOB in the two wetlands were quite different (Fig. 1c). The major dominant $\mathrm{AOB}$ in the coastal wetland was Nitrosospira-like. However, in the freshwater wetland, although the majority belonged to Nitrosospira-like, more than one third belonged to Nitrosomonas-like.

Diversity and community structures of anammox bacteria, $\mathrm{AOA}$, and $\mathrm{AOB}$

As discussed above, the freshwater wetland had broader AOP phylotypes than the coastal wetland. In addition to that, the diversities of AOPs in the freshwater wetland were also higher than those in the coastal wetland (Table 2). 
Furthermore, community structures of AOPs in the two wetlands were also different, as shown in PCoA results (Fig. 2). All these suggested that the wetland type had a strong influence on AOP community structures. Sediments of the coastal and freshwater wetlands had distinct physiochemical characteristics (Table 1), which might be responsible for the differences in the community structures of AOPs. The coastal wetland was restored from deserted salt pans approximately 40 years ago and planted with $K$. obovata. Because the restoring time was relatively short, $K$. obovata were still small (about $1 \mathrm{~m}$ in height). Therefore, the effects of $K$. obovata on AOPs were weak, but were evident at Mai Po Nature Reserve in Hong Kong where mangrove trees were more than 100 years old ( $\mathrm{Li}$ et al. 2011b). Furthermore, this wetland and the associated microorganisms were under regular tidal activity. Because of the relative homogeneity of the ecosystem and regular environmental factors, AOP communities were relatively simple. In the freshwater wetland, however, the situation was different. This wetland was transformed from fishponds. The input water was surface runoff from adjacent hills and wastewater from nearby villages. Different parts of the wetland were planted with different aquatic plants. All these made the ecosystem of the freshwater wetland more complex and heterogeneous, and the environmental factors were also very variable. As a result, the anammox bacterial community of the freshwater wetland was more complex than the coastal wetland.

Effects of different plants on the phylogeny and community structures of AOPs

Studies of mangrove sediments (Li et al. 2011b) and paddy soils (Wang and $\mathrm{Gu}$ 2012) indicated vegetation of plants might have an effect on anammox bacteria. For AOA, some studies showed plants affected the community composition (Chen et al. 2008; Herrmann et al. 2008), but others showed no effects at all (Herrmann et al. 2009). For AOB, some studies showed effects on the community composition (Briones et al. 2002; Chen et al. 2008; Herrmann et al. 2008), but others did not (Herrmann et al. 2009; Kowalchuk et al. 1998; Nicolaisen et al. 2004). In general, the effects of plant roots on the community composition in the rhizospheres are still controversial. In the freshwater wetland of the present study, $T$. angustifolia affected the community structure of anammox bacteria, but $P$. australis did not (Fig. 2a, b). For AOA, T. angustifolia had a strong effect and C. malaccensis had a weak one on the community structure (Fig. 2c, d). $P$. australis, T. angustifolia, and C. malaccensis all showed an influence on the community structure of AOB (Fig. 2e, f).

As plants could release exudates such as organic acids and transport oxygen into the rhizospheres ( $\mathrm{Lu}$ et al. 2007; Nikolausz et al. 2008), the physiochemical characteristics of the rhizospheres are usually different from those of the nonvegetated sediments. In addition to the redox potentials, other factors such as $\mathrm{NH}_{4}{ }^{+}$and $\mathrm{NO}_{2}{ }^{-}$concentrations in the rhizospheres were also different from the nonvegetated regions. Different plants have different abilities to change the characteristics of rhizospheres and, therefore, the community composition of AOPs. Anammox bacteria occur in oxygen-limited environments, such as oxic/anoxic interfaces (Jetten et al. 2009). Between the rhizospheres and bulk sediments, an oxic/anoxic interface exists. As a result, anammox bacterial community in the rhizospheres was different from that of nonvegetated areas (Li et al. 2011b). The oxic rhizosphere benefits AOA and AOB because these microorganisms frequently occur under oxic environments. T. angustifolia is exotic to Hong Kong. It is a fast-growing plant which has strong metabolism and changes the characteristics of the rhizosphere. In this study, T. angustifolia had a strong effect on the community structures of all AOPs in the rhizospheres. In addition to T. angustifolia, $P$. australis and $C$. malaccensis also showed a certain degree of effects on the community structures of AOB (Fig. 2).

Despite the fact that, in the freshwater wetland, some plants showed effects on community structures of AOPs, in the coastal wetland, $K$. obovata had no apparent effect on the community structures of all AOPs (Fig. 2). K. obovata trees growing in the coastal wetland were still small and the sediment samples in the vegetated site of $K$. obovata were from different layers rather than directly from the rhizospheres. As a consequence, the effect of $K$. obovata on AOP community might be weak in this study. Because of that, we could not exclude the possibility that larger $K$. obovata trees might have obvious effects on AOP community structures in the rhizospheres.

\section{Abundance of anammox bacterial 16S rRNA genes} and archaeal and bacterial amo $A$ genes

Abundances of AOPs in the coastal wetland were relatively evenly distributed between the sediment samples, whereas abundances of AOPs in the freshwater wetland were unevenly distributed by sites (Fig. 3). This is because the sediment samples in the coastal wetland were relatively homogeneous, while those in the freshwater wetland were very heterogeneous. In the coastal wetland, all sites were under the same effect of tidal activity and the sediments were quite homogeneous. Although vegetation had an effect on the sediments, the mangrove trees were still too small and the effect was not significant enough. In the freshwater wetland, water was collected and treated prior to being discharged into the wetland and the characteristics of the water were gradually changing from the inlet to the outlet of the wetland due to the self-purification. Abundances of AOPs varied from the inlet to the outlet accordingly. Specifically, 
AOA were undetectable in the $P$. australis site near the inlet of the wetland, and anammox bacteria were undetectable in the $C$. malaccensis site at the outlet. Ammonium concentration was relatively higher in the upstream than the downstream because of the treatment in action. Previous studies have shown that anammox bacteria favor high ammonium and AOA favor low ammonia. That is probably the reason AOA were undetectable in the upstream and anammox bacteria were undetectable in the downstream in the freshwater wetland.

Anammox bacterial 16S rRNA gene copies were relatively higher in the coastal wetland than in the freshwater wetland. Previous studies showed that anammox bacteria only exist in certain habitats, suggesting that some conditions such as oxic/anoxic interfaces and ammonia concentration are important factors determining the existence of anammox bacteria in natural environments (Jetten et al. 2009). Because of the regular influence of tidal activity, the sediments of the coastal wetland had more chances to form oxic/anoxic habitats. Furthermore, the average $\mathrm{NH}_{4}{ }^{+}$ concentration in the coastal wetland samples was higher than that in the freshwater wetland. As a consequence, the coastal marine wetland was more suitable for anammox bacteria to survive. Generally, freshwater wetland had lower AOB abundances than the coastal wetland, probably because sediment samples of the former had a lower ammonia concentration than the latter. AOA abundances in the freshwater wetland varied remarkably in different sites. In the $C$. malaccensis site, no AOA were detected. In the T. angustifolia site, AOA abundance was even higher than those of the coastal marine wetland. This result suggests that many factors codetermine the abundances of AOA.

Since the discovery of AOA, the relative importance of $\mathrm{AOB}$ or $\mathrm{AOA}$ in the ecosystem became a heated debate. $\mathrm{AOB}$ were found to numerically dominate over AOA in some habitats (Di et al. 2009), whereas AOA were found to outnumber AOB in many other environments (Adair and Schwartz 2008; Boyle-Yarwood et al. 2008; Cao et al. 2011b; Radax et al. 2012; Schauss et al. 2009). Although a significant number of studies emphasized the numerical competence of AOA, only four studies linked the nitrification rate with AOA abundance (reviewed by Pester et al. 2011). Furthermore, numerical dominance does not certainly represent functional importance, for example, Jia and Conrad (2009) demonstrated that, although AOA amoA genes numerically dominated an agricultural soil, AOB were responsible for ammonia oxidation. In the present study, AOA dominated over AOB in the freshwater wetland, with the exception of the $P$. australis site at the inlet where $\mathrm{NH}_{4}^{+}$concentration of water was relative high. In the coastal wetland, however, AOB dominated over AOA. The dominance of $\mathrm{AOB}$ or $\mathrm{AOA}$ in the environments is believed to be determined by some factors, such as ammonia concentration,
$\mathrm{pH}$, and organic matter. AOA have been demonstrated to be more competitive in low $\mathrm{NH}_{3}$ concentration because of their high affinity (Martens-Habbena et al. 2009). Some AOA species, such as $\mathrm{Ca}$. Nitrosotalea devanaterra, were demonstrated to favor low $\mathrm{pH}$ environments (Lehtovirta-Morley et al. 2011; Yao et al. 2011). Although both AOB and AOA were demonstrated to be chemolithoautotrophic organisms, some studies suggested that AOA are mixotrophic or even heterotrophic (Jia and Conrad 2009). In the present study, $\mathrm{NH}_{4}^{+}$ concentration and $\mathrm{pH}$ in the freshwater wetland were relatively lower than the coastal marine wetland, which are probably the reasons why AOA dominated the freshwater wetland and AOB dominated the coastal wetland. Although organic matter was not measured, the freshwater wetland in this study might have higher organic matter than the coastal wetland, which also facilitated the AOA existence in the freshwater wetland.

Due to the distinct physiochemical properties of the rhizospheres, communities of AOPs in the rhizospheres tend to be different from those in the bulk soils or nonvegetated soils. Herrmann et al. (2008) discovered that, in the rhizosphere of Littorella uniflora, AOA amoA genes were much more enriched compared with AOB amoA genes, suggesting that AOA were responsible for the enhanced nitrification activity observed in the rhizosphere. Subsequently, they further confirmed that L. uniflora and Juncus bulbosus harbored higher AOA abundances in the rhizospheres than in the nonvegetated soils (Herrmann et al. 2009). Another study showed that vegetation of Spartina alterniflora increased AOB numbers but reduced AOA numbers (Zhang et al. 2011). Studies on the effects of the rhizospheres on anammox bacteria are relatively scanty; Li et al. (2011b) suggested that mangrove trees might influence anammox bacterial abundances in the sediments. In the present study, $K$. obovata, P. australis, and C. malaccensis seemed to have no detectable effects on the abundances of anammox bacteria, $\mathrm{AOA}$, or $\mathrm{AOB}$ since the vegetated and nonvegetated sediments showed similar abundances of AOPs (Fig. 3). However, T. angustifolia seemed to be a special species. The abundances of anammox bacteria, AOA, and AOB in the rhizosphere of $T$. angustifolia were relatively higher than the nonvegetated sediment. This result suggested that $T$. angustifolia could enhance AOPs' quantity in the rhizosphere. In the future, it might be important to study why the exotic T. angustifolia enhances the quantity of AOPs.

In conclusion, AOPs in the vegetated and nonvegetated sediments in a coastal marine wetland and a freshwater wetland were investigated. The more heterogeneous freshwater wetland had a broader range of phylotypes, higher diversity, and more complex community structures of AOPs than the coastal marine wetland. Generally, the effects of vegetation on the community structures of AOPs were macrophyte species-specific. Vegetation of T. angustifolia had an apparent effect on the community structures of all AOPs. 
Vegetation of $P$. australis and $C$. malaccensis had some effect on the community structure of AOB but had little effect on the community structures of anammox bacteria and AOA. K. obovata showed almost no effect on the community structures of all AOPs. Information from this study allows further assessment of nutrient removal by wetland and the related functional groups of microorganisms responsible for the treatment efficiency. In addition, better management of wetland may be achieved through fundamental understanding of the microbial community structures.

Acknowledgments This research was supported in part by a Ph.D. studentship (Y-FW) from the Graduate School of The University of Hong Kong. Additional financial support of this project was from the Environment and Conservation Fund of Hong Kong project number 15/2011 and the Environmental Toxicology Education and Research Fund of this laboratory. We would like to thank Simon Chan and Jackie Yip of the Agriculture, Fisheries and Conservation Department of the Hong Kong SAR Government for their support in the sampling of the wetlands and Ms. Jessie Lai for the support in the field sampling and chemical analysis.

Open Access This article is distributed under the terms of the Creative Commons Attribution License which permits any use, distribution, and reproduction in any medium, provided the original author(s) and the source are credited.

\section{References}

Adair KL, Schwartz E (2008) Evidence that ammonia-oxidizing archaea are more abundant than ammonia-oxidizing bacteria in semiarid soils of northern Arizona, USA. Microb Ecol 56:420-426

Altschul SF, Gish W, Miller W, Myers EW, Lipman DJ (1990) Basic local alignment search tool. J Mol Biol 215:403-410

Boyle-Yarwood SA, Bottomley PJ, Myrold DD (2008) Community composition of ammonia-oxidizing bacteria and archaea in soils under stands of red alder and Douglas fir in Oregon. Environ Microbiol 10:2956-2965

Brandes JA, Devol AH, Deutsch C (2007) New developments in the marine nitrogen cycle. Chem Rev 107:577-589

Briones AM, Okabe S, Umemiya Y, Ramsing N-B, Reichardt W, Okuyama H (2002) Influence of different cultivars on populations of ammonia-oxidizing bacteria in the root environment of rice. Appl Environ Microbiol 68:3067-3075

Brochier-Armanet C, Boussau B, Gribaldo S, Forterre P (2008) Mesophilic Crenarchaeota: proposal for a third archaeal phylum, the Thaumarchaeota. Nat Rev Micro 6:245-252

Cao H, Li M, Dang H, Gu J-D (2011a) Responses of aerobic and anaerobic ammonia/ammonium-oxidizing microorganisms to anthropogenic pollution in coastal marine environments. Methods Enzymol 496:35-62

Cao H, Li M, Hong Y, Gu J-D (2011b) Diversity and abundance of ammonia-oxidizing archaea and bacteria in polluted mangrove sediment. Syst Appl Microbiol 34:513-523

Cao H, Hong Y, Li M, Gu J-D (2012) Community shift of ammoniaoxidizing bacteria along an anthropogenic pollution gradient from the Pearl River Delta to the South China Sea. Appl Microbiol Biotechnol 94:247-259

Chen X-P, Zhu Y-G, Xia Y, Shen J-P, He J-Z (2008) Ammoniaoxidizing archaea: important players in paddy rhizosphere soil? Environ Microbiol 10:1978-1987
Clark I, Timlin R, Bourbonnais A, Jones K, Lafleur D, Wickens K (2008) Origin and fate of industrial ammonium in anoxic ground water $-{ }^{15} \mathrm{~N}$ evidence for anaerobic oxidation (anammox). Ground Water Monit Remediat 28:73-82

Cole JR, Chai B, Farris RJ, Wang Q, Kulam SA, McGarrell DM, Garrity GM, Tiedje JM (2005) The Ribosomal Database Project (RDP-II): sequences and tools for high-throughput rRNA analysis. Nucleic Acids Res 33:D294-D296

Dale OR, Tobias CR, Song B (2009) Biogeographical distribution of diverse anaerobic ammonium oxidizing (anammox) bacteria in Cape Fear River Estuary. Environ Microbiol 11:1194-1207

Dang H, Chen R, Wang L, Guo L, Chen P, Tang Z, Tian F, Li S, Klotz MG (2010) Environmental factors shape sediment anammox bacterial communities in hypernutrified Jiaozhou Bay, China. Appl Environ Microbiol 76:7036-7047

Di HJ, Cameron KC, Shen JP, Winefield CS, O'Callaghan M, Bowatte $\mathrm{S}$, He JZ (2009) Nitrification driven by bacteria and not archaea in nitrogen-rich grassland soils. Nat Geosci 2:621-624

Ding X, Fu L, Liu C, Chen F, Hoffland E, Shen J, Zhang F, Feng G (2011) Positive feedback between acidification and organic phosphate mineralization in the rhizosphere of maize (Zea mays L.). Plant Soil 349:13-24

Francis CA, Roberts KJ, Beman JM, Alyson ES, Oakley BB (2005) Ubiquity and diversity of ammonia-oxidizing archaea in water columns and sediments of the ocean. Proc Natl Acad Sci 102:1468314688

Glaser K, Hackl E, Inselsbacher E, Strauss J, Wanek W, ZechmeisterBoltenstern S, Sessitsch A (2010) Dynamics of ammoniaoxidizing communities in barley-planted bulk soil and rhizosphere following nitrate and ammonium fertilizer amendment. FEMS Microbiol Ecol 74:575-591

Gopal B, Ghosh D (2008) Natural wetlands. In: Sven Erik J, Brian F (eds) Encyclopedia of ecology. Academic, Oxford, pp 2493-2504

Hamady M, Lozupone C, Knight R (2009) Fast UniFrac: facilitating high-throughput phylogenetic analyses of microbial communities including analysis of pyrosequencing and PhyloChip data. ISME J 4:17-27

Hamersley MR, Woebken D, Boehrer B, Schultze M, Lavik G, Kuypers MMM (2009) Water column anammox and denitrification in a temperate permanently stratified lake (Lake Rassnitzer, Germany). Syst Appl Microbiol 32:571-582

Harhangi HR, Le Roy M, van Alen T, B-1 H, Groen J, Kartal B, Tringe SG, Quan Z-X, Jetten MSM, Op den Camp HJM (2012) Hydrazine synthase, a unique phylomarker with which to study the presence and biodiversity of anammox bacteria. Appl Environ Microbiol 78:752-758

Herrmann M, Saunders AM, Schramm A (2008) Archaea dominate the ammonia-oxidizing community in the rhizosphere of the freshwater macrophyte Littorella uniflora. Appl Environ Microbiol 74:32793283

Herrmann M, Saunders AM, Schramm A (2009) Effect of lake trophic status and rooted macrophytes on community composition and abundance of ammonia-oxidizing prokaryotes in freshwater sediments. Appl Environ Microbiol 75:3127-3136

Hirsch M, Long Z, Song B (2011) Anammox bacterial diversity in various aquatic ecosystems based on the detection of hydrazine oxidase genes $(h z o A / h z o B)$. Microb Ecol 61:264-276

Hong Y-G, Li M, Cao H, Gu J-D (2011) Residence of habitat-specific anammox bacteria in the deep-sea subsurface sediments of the South China Sea: analyses of marker gene abundance with physical chemical parameters. Microb Ecol 62:36-47

Humbert S, Tarnawski S, Fromin N, Mallet M-P, Aragno M, Zopfi J (2009) Molecular detection of anammox bacteria in terrestrial ecosystems: distribution and diversity. ISME J 4:450-454

Jaeschke A, Op den Camp HJM, Harhangi H, Klimiuk A, Hopmans EC, Jetten MSM, Schouten S, Sinninghe Damsté JS (2009) 16S rRNA 
gene and lipid biomarker evidence for anaerobic ammoniumoxidizing bacteria (anammox) in California and Nevada hot springs. FEMS Microbiol Ecol 67:343-350

Jetten MSM, Strous M, van de Pas-Schoonen KT, Schalk J, van Dongen UGJM, van de Graaf AA, Logemann S, Muyzer G, van Loosdrecht MCM, Kuenen JG (1998) The anaerobic oxidation of ammonium. FEMS Microbiol Rev 22:421-437

Jetten MSM, Lv N, Strous M, Kartal B, Keltjens JT, Op den Camp HJM (2009) Biochemistry and molecular biology of anammox bacteria. Crit Rev Biochem Mol Biol 44:65-84

Jia Z, Conrad R (2009) Bacteria rather than Archaea dominate microbial ammonia oxidation in an agricultural soil. Environ Microbiol 11:1658-1671

Kartal B, Koleva M, Arsov R, van der Star W, Jetten MSM, Strous M (2006) Adaptation of a freshwater anammox population to high salinity wastewater. J Biotechnol 126:546-553

Kartal B, Rattray J, van Niftrik LA, van de Vossenberg J, Schmid MC, Webb RI, Schouten S, Fuerst JA, Damsté Jaap S, Jetten MSM, Strous M (2007) Candidatus "Anammoxoglobus propionicus" a new propionate oxidizing species of anaerobic ammonium oxidizing bacteria. Syst Appl Microbiol 30:39-49

Kartal B, Kuenen JG, van Loosdrecht MCM (2010) Sewage treatment with anammox. Science 328:702-703

Könneke M, Bernhard AE, de la Torre JR, Walker CB, Waterbury JB, Stahl DA (2005) Isolation of an autotrophic ammonia-oxidizing marine archaeon. Nature 437:543-546

Kowalchuk GA, Stephen JR (2001) Ammonia-oxidizing bacteria: a model for molecular microbial ecology. Annu Rev Microbiol 55:485-529

Kowalchuk GA, Bodelier PLE, Heilig GHJ, Stephen JR, Laanbroek HJ (1998) Community analysis of ammonia-oxidising bacteria, in relation to oxygen availability in soils and root-oxygenated sediments, using PCR, DGGE and oligonucleotide probe hybridisation. FEMS Microbiol Ecol 27:339-350

Kuypers MMM, Sliekers AO, Lavik G, Schmid M, Jorgensen BB, Kuenen JG, Sinninghe Damsté JS, Strous M, Jetten MSM (2003) Anaerobic ammonium oxidation by anammox bacteria in the Black Sea. Nature 422:608-611

Kuypers MMM, Lavik G, Woebken D, Schmid M, Fuchs BM, Amann R, Jørgensen BB, Jetten MSM, Hayes JM (2005) Massive nitrogen loss from the Benguela upwelling system through anaerobic ammonium oxidation. Proc Natl Acad Sci 102:6478-6483

Ladygina N, Hedlund K (2010) Plant species influence microbial diversity and carbon allocation in the rhizosphere. Soil Biol Biochem 42:162-168

Lam P, Lavik G, Jensen MM, van de Vossenberg J, Schmid M, Woebken D, Gutiérrez D, Amann R, Jetten MSM, Kuypers MMM (2009) Revising the nitrogen cycle in the Peruvian oxygen minimum zone. Proc Natl Acad Sci 106:4752-4757

Lehtovirta-Morley LE, Stoecker K, Vilcinskas A, Prosser JI, Nicol GW (2011) Cultivation of an obligate acidophilic ammonia oxidizer from a nitrifying acid soil. Proc Natl Acad Sci 108:15892-15897

Li H, Chen S, Mu BZ, Gu J-D (2010a) Molecular detection of anaerobic ammonium-oxidizing (anammox) bacteria in high-temperature petroleum reservoirs. Microb Ecol 60:771-783

Li M, Hong Y, Klotz M, Gu J-D (2010b) A comparison of primer sets for detecting 16S rRNA and hydrazine oxidoreductase genes of anaerobic ammonium-oxidizing bacteria in marine sediments. Appl Microbiol Biotechnol 86:781-790

Li M, Gu J-D (2011) Advances in methods for detection of anaerobic ammonium oxidizing (anammox) bacteria. Appl Microbiol Biotechnol 90:1241-1252

Li M, Ford T, Li X, Gu J-D (2011a) Cytochrome $c d$ l-containing nitrite reductase encoding gene nirS as a new functional biomarker for detection of anaerobic ammonium oxidizing (anammox) bacteria. Environ Sci Technol 45:3547-3553

Li M, Hong Y-G, Cao H-L, Gu J-D (2011b) Mangrove trees affect the community structure and distribution of anammox bacteria at an anthropogenic-polluted mangrove in the Pearl River Delta reflected by $16 \mathrm{~S}$ rRNA and hydrazine oxidoreductase (HZO) encoding gene analyses. Ecotoxicology 20:1780-1790

Lu H, Yan C, Liu J (2007) Low-molecular-weight organic acids exuded by mangrove (Kandelia candel (L.) Druce) roots and their effect on cadmium species change in the rhizosphere. Environ Exp Bot 61:159-166

Martens-Habbena W, Berube PM, Urakawa H, de la Torre JR, Stahl DA (2009) Ammonia oxidation kinetics determine niche separation of nitrifying Archaea and Bacteria. Nature 461:976-979

Michael T (2010) Assessing the cost-effectiveness of the water purification function of wetlands for environmental planning. Ecol Complex 7:320-326

Mulder A, van de Graaf AA, Robertson LA, Kuenen JG (1995) Anaerobic ammonium oxidation discovered in a denitrifying fluidized bed reactor. FEMS Microbiol Ecol 16:177-183

Nagelkerken I, Blaber SJM, Bouillon S, Green P, Haywood M, Kirton LG, Meynecke JO, Pawlik J, Penrose HM, Sasekumar A, Somerfield PJ (2008) The habitat function of mangroves for terrestrial and marine fauna: a review. Aquat Bot 89:155-185

Nicolaisen MH, Risgaard-Petersen N, Revsbech NP, Reichardt W, Ramsing NB (2004) Nitrification-denitrification dynamics and community structure of ammonia oxidizing bacteria in a high yield irrigated Philippine rice field. FEMS Microbiol Ecol 49:359-369

Nikolausz M, Kappelmeyer U, Székely A, Rusznyák A, Márialigeti K, Kästner M (2008) Diurnal redox fluctuation and microbial activity in the rhizosphere of wetland plants. Eur J Soil Biol 44:324-333

Nye P (1981) Changes of $\mathrm{pH}$ across the rhizosphere induced by roots. Plant Soil 61:7-26

Okabe S, Satoh H, Watanabe Y (1999) In situ analysis of nitrifying biofilms as determined by in situ hybridization and the use of microelectrodes. Appl Environ Microbiol 65:3182-3191

Penton CR, Devol AH, Tiedje JM (2006) Molecular evidence for the broad distribution of anaerobic ammonium-oxidizing bacteria in freshwater and marine sediments. Appl Environ Microbiol 72:6829-6832

Pester M, Schleper C, Wagner M (2011) The Thaumarchaeota: an emerging view of their phylogeny and ecophysiology. Curr Opin Microbiol 14:300-306

Pester M, Rattei T, Flechl S, Gröngröft A, Richter A, Overmann J, Reinhold-Hurek B, Loy A, Wagner M (2012) amoA-based consensus phylogeny of ammonia-oxidizing archaea and deep sequencing of amoA genes from soils of four different geographic regions. Environ Microbiol 14:525-539

Pommerening-Röser A, Rath G, Koops HP (1996) Phylogenetic diversity within the genus Nitrosomonas. Syst Appl Microbiol 19:344-351

Purkhold U, Pommerening-Röser A, Juretschko S, Schmid MC, Koops H-P, Wagner M (2000) Phylogeny of all recognized species of ammonia oxidizers based on comparative 16S rRNA and amoA sequence analysis: implications for molecular diversity surveys. Appl Environ Microbiol 66:5368-5382

Quan Z-X, Rhee S-K, Zuo J-E, Yang Y, Bae J-W, Park JR, Lee S-T, Park Y-H (2008) Diversity of ammonium-oxidizing bacteria in a granular sludge anaerobic ammonium-oxidizing (anammox) reactor. Environ Microbiol 10:3130-3139

Radax R, Hoffmann F, Rapp HT, Leininger S, Schleper C (2012) Ammonia-oxidizing archaea as main drivers of nitrification in cold-water sponges. Environ Microbiol 14:909-923

Rotthauwe J, Witzel K, Liesack W (1997) The ammonia monooxygenase structural gene $a m o A$ as a functional marker: molecular finescale analysis of natural ammonia-oxidizing populations. Appl Environ Microbiol 63:4704-4712 
Rysgaard S, Glud RN (2004) Anaerobic $\mathrm{N}_{2}$ production in Arctic Sea ice. Limnol Oceanogr 49:86-94

Schauss K, Focks A, Leininger S, Kotzerke A, Heuer H, Thiele-Bruhn S, Sharma S, Wilke B-M, Matthies M, Smalla K, Munch JC, Amelung W, Kaupenjohann M, Schloter M, Schleper C (2009) Dynamics and functional relevance of ammonia-oxidizing archaea in two agricultural soils. Environ Microbiol 11:446-456

Schleper C (2010) Ammonia oxidation: different niches for bacteria and archaea? ISME J 4:1092-1094

Schloss PD, Handelsman J (2005) Introducing DOTUR, a computer program for defining operational taxonomic units and estimating species richness. Appl Environ Microbiol 71:1501-1506

Schmid M, Twachtmann U, Klein M, Strous M, Juretschko S, Jetten M, Metzger JW, Schleifer K-H, Wagner M (2000) Molecular evidence for genus level diversity of bacteria capable of catalyzing anaerobic ammonium oxidation. Syst Appl Microbiol 23:93-106

Schmid M, Walsh K, Webb R, Rijpstra WI, van de Pas-Schoonen K, Verbruggen MJ, Hill T, Moffett B, Fuerst J, Schouten S, Damsté JSS, Harris J, Shaw P, Jetten M, Strous M (2003) Candidatus "Scalindua brodae", sp. nov., Candidatus "Scalindua wagneri", sp. nov., two new species of anaerobic ammonium oxidizing bacteria. Syst Appl Microbiol 26:529-538

Schmid MC, Risgaard-Petersen N, Vossenberg J, Kuypers MMM, Lavik G, Petersen J, Hulth S, Thamdrup B, Canfield D, Dalsgaard T, Rysgaard S, Sejr MK, Strous M, Op den Camp HJM, Jetten MSM (2007) Anaerobic ammonium-oxidizing bacteria in marine environments: widespread occurrence but low diversity. Environ Microbiol 9:1476-1484

Schmid MC, Hooper AB, Klotz MG, Woebken D, Lam P, Kuypers MMM, Pommerening-Roeser A, Op den Camp HJM, Jetten MSM (2008) Environmental detection of octahaem cytochrome $c$ hydroxylamine/hydrazine oxidoreductase genes of aerobic and anaerobic ammonium-oxidizing bacteria. Environ Microbiol 10:3140-3149

Schubert CJ, Durisch-Kaiser E, Wehrli B, Thamdrup B, Lam P, Kuypers MMM (2006) Anaerobic ammonium oxidation in a tropical freshwater system (Lake Tanganyika). Environ Microbiol 8:1857-1863
Soda S, Ike M, Ogasawara Y, Yoshinaka M, Mishima D, Fujita M (2007) Effects of light intensity and water temperature on oxygen release from roots into water lettuce rhizosphere. Water Res 41:487-491

Strous M, Fuerst JA, Kramer EHM, Logemann S, Muyzer G, van de Pas-Schoonen KT, Webb R, Kuenen JG, Jetten MSM (1999) Missing lithotroph identified as new planctomycete. Nature 400:446-449

Tamura K, Peterson D, Peterson N, Stecher G, Nei M, Kumar S (2011) MEGA5: molecular evolutionary genetics analysis using maximum likelihood, evolutionary distance, and maximum parsimony methods. Mol Biol Evol 28:2731-2739

Wang J, Gu J-D (2012) Dominance of Candidatus Scalindua species in anammox community revealed in soils with different duration of rice paddy cultivation in Northeast China. Appl Microbiol Biotechnol. doi:10.1007/s00253-012-4036-x

Winogradsky S (1890) Investigations on nitrifying organisms. Ann Inst Pasteur 4:213-321

Yao H, Gao Y, Nicol GW, Campbell CD, Prosser JI, Zhang L, Han W, Singh BK (2011) Links between ammonia oxidizer community structure, abundance, and nitrification potential in acidic soils. Appl Environ Microbiol 77:4618-4625

Zhang Y, Ruan X-H, Op den Camp HJM, Smits TJM, Jetten MSM, Schmid MC (2007) Diversity and abundance of aerobic and anaerobic ammonium-oxidizing bacteria in freshwater sediments of the Xinyi River (China). Environ Microbiol 9:2375-2382

Zhang CL, Ye Q, Huang Z, Li W, Chen J, Song Z, Zhao W, Bagwell C, Inskeep WP, Ross C, Gao L, Wiegel J, Romanek CS, Shock EL, Hedlund BP (2008) Global occurrence of archaeal amo $A$ genes in terrestrial hot springs. Appl Environ Microbiol 74:6417-6426

Zhang D, Gersberg RM, Keat TS (2009) Constructed wetlands in China. Ecol Eng 35:1367-1378

Zhang QF, Peng JJ, Chen Q, Li XF, Xu CY, Yin HB, Yu S (2011) Impacts of Spartina alterniflora invasion on abundance and composition of ammonia oxidizers in estuarine sediment. J Soils Sed 11:1020-1031 